\title{
Tamm Review: Observed and projected climate change impacts on Russia's forests and its carbon balance
}

\author{
Sibyll Schaphoff ${ }^{\mathrm{a}, *}$, Christopher P.O. Reyer ${ }^{\mathrm{a}}$, Dmitry Schepaschenko ${ }^{\mathrm{b}, \mathrm{c}}$, Dieter Gerten ${ }^{\mathrm{a}}$, \\ Anatoly Shvidenko ${ }^{\mathrm{b}, \mathrm{d}}$ \\ a Potsdam Institute for Climate Impact Research, Telegraphenberg A62, D-14473 Potsdam, Germany \\ b International Institute for Applied Systems Analysis, Schlossplatz 1, A-2361 Laxenburg, Austria \\ ${ }^{\mathrm{c}}$ Moscow State Forest University, Institutskaya 1, Mytishchi, Moscow Oblast 141005, Russia \\ ${ }^{\mathrm{d}}$ Sukachev Institute of Forest, Siberian Division, Russian Academy of Sciences, Akademgorodok, str. 28, Krasnoyarsk 660041, Russia
}

\section{A R T I C L E I N F O}

\section{Article history:}

Received 27 February 2015

Received in revised form 20 November 2015

Accepted 23 November 2015

Available online $\mathrm{xxxx}$

\section{Keywords:}

Boreal forests

Tipping point

Carbon balance

Carbon pools

Permafrost

Forest productivity

Fire

Insects

\begin{abstract}
A B S T R A C T
Russia's boreal forests provide numerous important ecosystem functions and services, but they are being increasingly affected by climate change. This review presents an overview of observed and potential future climate change impacts on those forests with an emphasis on their aggregate carbon balance and processes driving changes therein. We summarize recent findings highlighting that radiation increases, temperature-driven longer growing seasons and increasing atmospheric $\mathrm{CO}_{2}$ concentrations generally enhance vegetation productivity, while heat waves and droughts tend to decrease it. Estimates of major carbon fluxes such as net biome production agree that the Russian forests as a whole currently act as a carbon sink, but these estimates differ in terms of the magnitude of the sink due to different methods and time periods used. Moreover, models project substantial distributional shifts of forest biomes, but they may overestimate the extent to which the boreal forest will shift poleward as past migration rates have been slow. While other impacts of current climate change are already substantial, and projected impacts could be both large-scale and disastrous, the likelihood for a tipping point behavior of Russia's boreal forest is still unquantified. Other substantial research gaps include the large-scale effect of (climate-driven) disturbances such as fires and insect outbreaks, which are expected to increase in the future. We conclude that the impacts of climate change on Russia's boreal forest are often superimposed by other environmental and societal changes in a complex way, and the interaction of these developments could exacerbate both existing and projected future challenges. Hence, development of adaptation and mitigation strategies for Russia's forests is strongly advised.
\end{abstract}

(c) 2015 Elsevier B.V. All rights reserved.

\section{Contents}

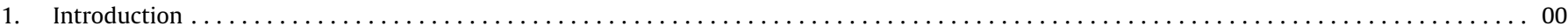

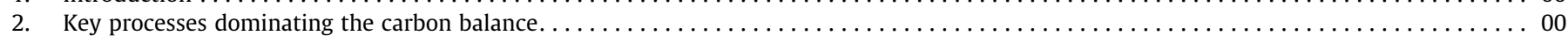

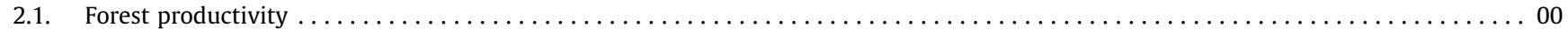

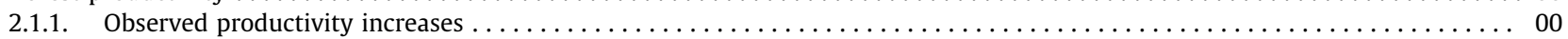

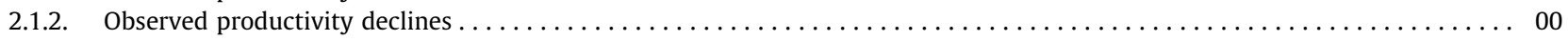

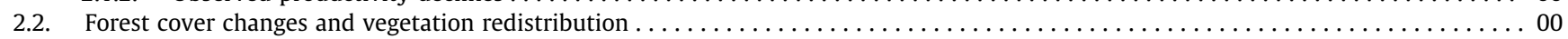

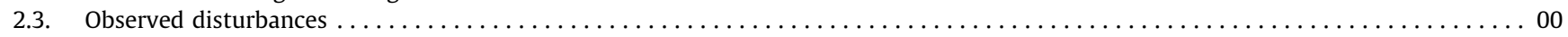

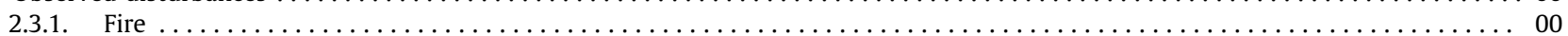

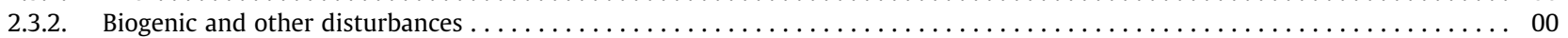

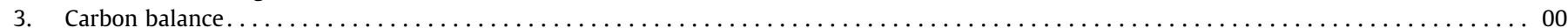

Abbreviations: LB, live biomass; RWI, ring width increment; NBP, net biome production; NPP, net primary production; HR, heterotrophic respiration; DGVM, Dynamic Global Vegetation Model; CI, confidential interval; T, temperature; CWD, coarse woody debris.

* Corresponding author.

E-mail address: Sibyll.Schaphoff@pik-potsdam.de (S. Schaphoff). 


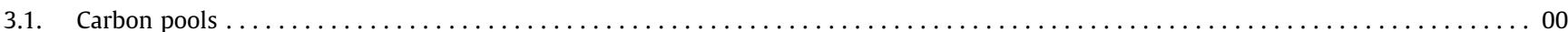

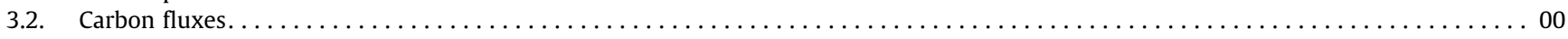

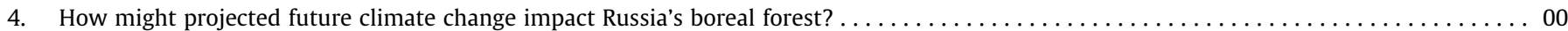

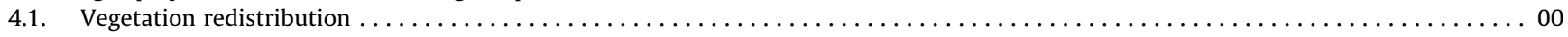

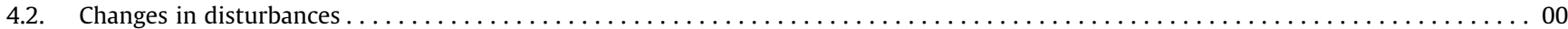

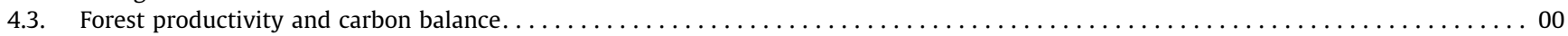

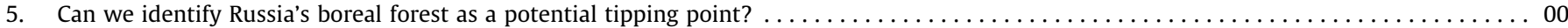

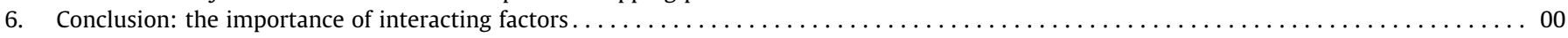

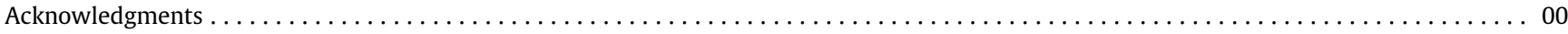

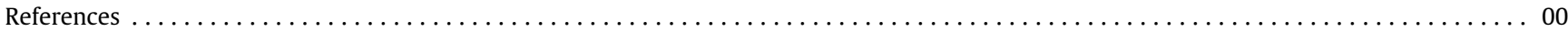

\section{Introduction}

Global climate change mitigation discussions need to focus more on boreal forests (Gauthier et al., 2015). Such a focus is necessary because of the significant importance of these forests for the climate system itself, mediated through biosphere-atmosphere exchanges of water, carbon and energy. The two dominating feedbacks are changes in reflectance and energy exchange that result from the loss or gain of evergreen coniferous vegetation at high latitudes and changes in carbon cycling (Betts, 2000; Bonan, 2008; O'Halloran et al., 2012). The latter is particularly relevant for Russia's boreal forests because they cover a huge and widely pristine area $(>90 \%$ of the total Russian forest cover, i.e. 900 Mha; Shvidenko et al., 2013), storing huge amounts of carbon. Actually, about half of the terrestrial global carbon

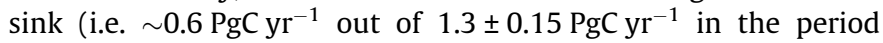
2000-2009, after subtraction of land use change emissions) is estimated to be located in Russia's forests (Dolman et al., 2012; Schaphoff et al., 2013). Yet, compared to the many existing studies of climate change impacts on Canada's (e.g. Peng et al., 2011; Price et al., 2013) and Fennoscandia's (e.g. Ge et al., 2013) boreal forests, proportionally little is known for Russia's boreal forests specifically, despite their great importance locally, regionally and globally - hence our present review.

Warming in the boreal region in Russia has been stronger than in the global mean, while precipitation changes are regionally specific (Hansen et al., 2006, 2010). These ongoing changes in climate alter Russia's boreal forests in various ways. Climate change induces manifold physiological and structural responses of the vegetation cover of Russia's boreal forest, which are basically governed by processes that limit tree growth, i.e. primarily low growing season temperature, low solar radiation, and low nitrogen availability (Boisvenue and Running, 2006). Droughts and heat waves associated with a long-term change in background climate can accelerate or intensify forest diseases, insect outbreaks and fire activity, leading to increased tree mortality. Different feedbacks of boreal forests to change in climate and environment were already observed in Russian forests. Statistically significant change of ratio between live biomass of stems, roots and foliage was reported for the country's forests during 1961-2002 (Lapenis et al., 2005). A widespread increase of tree mortality over the entire Russian boreal belt has been confirmed (Allen et al., 2010), although drought-i.e. increasing water demand of plants induced by higher temperatures in vast continental regions-is not the only driver of this phenomenon (Shvidenko et al., 2013; Steinkamp and Hickler, 2015). With continuing and accelerating climate change, there is a risk that the boreal forest may even cross a tipping point and shift to an alternative state (Chapin et al., 2005; Lenton et al., 2008; Scheffer et al., 2012). Other prospective impacts of future climate change on forest ecosystems in Russia, as documented in Russian-language literature, have been reviewed by Sharmina et al. (2013). They found that the key anticipated impacts are potential shifts of vegetation zones, more frequent and intensive wildfires, and increased plant productivity through $\mathrm{CO}_{2}$ fertilization. These potential changes would substantially reduce the carbon sink capacity of the boreal zone (Koven et al., 2011; Schaphoff et al., 2006, 2013), accelerated by warming-induced permafrost melting (Romanovsky et al., 2010). The latter is a crucial process as the Russian boreal forest zone stores a massive amount of carbon in permafrost soils and wetlands (Zimov et al., 2006; Tarnocai et al., 2009; Schepaschenko et al., 2013).

The objective of this paper is to present an overview of observed and potential future climate change impacts on Russia's boreal forests based on a comprehensive review of the recent scientific literature and to synthesize existing knowledge for assessing the regional distribution of impacts and key underlying mechanisms. We streamline the review toward an assessment of Russia's carbon budget and balance because of its global importance, which has been emphasized in many studies (Gauthier et al., 2015; Malhi et al., 1999). We do so by first discussing observed changes in those key processes that dominate the Russian carbon balance and that are particularly affected by climate change, namely forest productivity, forest distribution and disturbances. Then we summarize the recent literature on observed changes in the carbon balance. In order to provide future perspectives, we finally summarize projected changes in the key processes and the future carbon balance. We close by briefly discussing the likelihood of a tipping of Russia's boreal forest. We rely on regional studies within the boreal forest of Russia and on global studies that have sufficient granularity to single out Russian forests. For more general process descriptions we also consider scientific literature on boreal forests outside Russian territory.

\section{Key processes dominating the carbon balance}

\subsection{Forest productivity}

Forest productivity in the northern latitudes depends on a variety of interacting climatic and non-climatic factors (Table 1). Among the governing climatic factors are solar radiation, temperature, direct effects of atmospheric $\mathrm{CO}_{2}$ concentration and nitrogen deposition (Chapin et al., 2005; Ciais et al., 2005) as well as water availability and the seasonality of precipitation (Berner et al., 2013). Other factors relevant for forest productivity-impacts of which may be modulated by climatic conditions-are fires, insect outbreaks, and diseases that have been shown to counteract forest growth stimulation by increased temperature (Zamolodchikov et al., 2013).

Recent analyses of Normalized Differenced Vegetation Index (NDVI) data, used as a proxy for terrestrial Gross Primary Production (GPP), explored the spatial and temporal variability of 'greening' (enhanced productivity) and 'browning' patterns (lower productivity) in the boreal zone (Beck et al., 2011; Bunn and Goetz, 2006; Goetz et al., 2007; de Jong et al., 2011). Furthermore, tree ring studies have identified complex patterns of tree growth in response to past climate variability (Lloyd and Bunn, 2007). Table 1 
Table 1

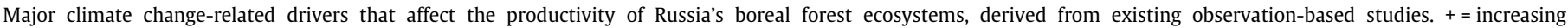
productivity; - = decreasing productivity.

\begin{tabular}{|c|c|c|c|}
\hline Driver & Response & Methods & References \\
\hline Radiation increase & + & $\begin{array}{l}\text { Inventory data of growing stock volume, NDVI data set } \\
\text { from Advanced Very High Resolution Radiometer } \\
\text { (AVHRR), measurements of tree ring-widths }\end{array}$ & $\begin{array}{l}\text { Myneni et al. (1997), Ichii et al. (2013), } \\
\text { Berner et al. (2013) }\end{array}$ \\
\hline Heat waves & - & MODIS productivity indexes & Bastos et al. (2014) \\
\hline $\mathrm{CO}_{2}$ increase & + & NDVI, LAI, and FPAR from AVHRR & Ichii et al. (2013), Kharuk et al. (2011, 2014) \\
\hline $\begin{array}{l}\text { Growing season } \\
\text { lengthening }\end{array}$ & $\begin{array}{l}+ \\
\text { Early spring and delayed end } \\
\text { of growing season }\end{array}$ & $\begin{array}{l}\text { NDVI, LAI, and FPAR from AVHRR, measurements of tree } \\
\text { ring-widths }\end{array}$ & $\begin{array}{l}\text { Jeong et al. (2011), Berner et al. (2013), Ichii et al. } \\
\text { (2013), Myneni et al. (1997) }\end{array}$ \\
\hline Water availability & $\begin{array}{l} \pm \\
\text { Season dependent }\end{array}$ & Tree-ring width measurements; NDVI from AVHRR & $\begin{array}{l}\text { Kharuk et al. (2006), Devi et al. (2008), Berner } \\
\text { et al. (2013) }\end{array}$ \\
\hline Drought stress & $\begin{array}{l}\text { Decreased NPP, increased } \\
\text { forest mortality }\end{array}$ & MODIS-derived enhanced vegetation index & Kharuk et al. (2013), Shvidenko et al. (2013) \\
\hline
\end{tabular}

shows that generally climate change-induced changes in drivers of productivity may have positive or negative effects on forest productivity. These are outlined in the next sections.

\subsubsection{Observed productivity increases}

Observed productivity increases are mostly related to increasing temperatures, $\mathrm{e}\left[\mathrm{CO}_{2}\right]$ and precipitation. It has been widely shown that temperature increases leading to a lengthening of the growing season on average stimulate forest growth in the Russian boreal zone (Berner et al., 2013; Ichii et al., 2013; Myneni et al., 1997). A satellite imagery-based study by Jeong et al. (2011) observed an earlier onset and a delayed end of the growing season in Eurasia. They estimated that from 1982 to 1999 the growing season increased by $>0.8$ days per year in accordance with a significant warming of $>0.15^{\circ} \mathrm{C}$ per year. Piao et al. (2008) have suggested that autumn warming leads to increases in net primary production (NPP) and even more so in gross primary production (GPP) in Eurasia's boreal forest. An evaluation of remote sensing data shows greening trends in the transition zone to tundra and wetlands since the 1990s (Beck and Goetz, 2012; Bunn and Goetz, 2006). Similarly, Lloyd et al. (2011) provided evidence that warming has an NPP-stimulating effect at northern sites in particular. Greening is thus more often observed in colder areas, and is most evident in areas of low tree cover (Berner et al., 2013). However, positive trends in NDVI data might reflect enhanced understorey and green forest floor growth, particularly in high latitudes, rather than increased tree growth (Berner et al., 2011); it might also indicate a changing carbon allocation pattern from woody parts to green plant material (Lapenis et al., 2005).

Furthermore, $\mathrm{CO}_{2}$ fertilization and increased precipitation have promoted vegetation greening in some regions (Ichii et al., 2013). Kharuk et al. (2014) showed substantial acceleration of growth of birch forests in southern Siberia and significant positive correlation between biometric indicators of stands and vegetation period length and atmospheric $\mathrm{CO}_{2}$ concentration, as well as negative correlation with a drought index. The correlation between radial growth of Siberian larch and rising $\mathrm{CO}_{2}$ concentration was also reported for the Alpine ecotone in the Altai-Sayan Mountains (Kharuk et al., 2011). Berner et al. (2013) revealed that tree growth depends on the seasonality of precipitation in that growth was enhanced when the summer was wetter than normal. This suggests that if water availability is sufficient, future warming could promote plant growth and forest expansion along the Arctic tree line (Berner et al., 2013; Devi et al., 2008; MacDonald et al., 2008). However, Tchebakova et al. (2009) suggested that in larch forests other factors, potentially related to permafrost dynamics, play a substantial role as well. Recent satellite data show that warming has indeed increased NPP north of $47.5^{\circ}$ over the decade 2000-2009 in spite of a concurrent drying trend in large, mostly continental regions (Zhao and Running, 2010). However, over the Siberian forest this reported increase was heterogeneous, with an extensive negative trend over the western part and a positive trend of the eastern part (Zhao and Running, 2010).

Overall, based on regional analysis of forest inventory data and series of measurements in situ, the increase of productivity of Russian forests during the last 50 years, expressed in terms of increasing growing stock volume for comparable categories of forests, was estimated to be $+0.2 \%$ to $+0.5 \%$ per year. However, this process was regionally modified by climate, management and different disturbance regimes (Alexeyev and Markov, 2003; Shvidenko et al., 2007a). Similar results have been found by Sennov (1999) who reported a substantial increase of net growth of major boreal forest forming species based on series of permanent sample plots in a south taiga region near Saint-Petersburg. We conclude that there is evidence for increasing productivity regionally as an interaction of higher temperatures, longer growing seasons and increasing water availability.

\subsubsection{Observed productivity declines}

Observed productivity declines are mostly related to heat and drought stress. Many trees in northeastern Siberia exhibited a general downward trend in basal area increment after the mid-20th century (Berner et al., 2013). Lloyd and Bunn (2007) pointed out that most browning occurred in the most recent time period. A spatial analysis of $\sim 180$ tree-ring chronologies showed large differences in temperature changes and tree growth trends along the northern tree line in Russia after the 1960s. The underlying reasons were explained by interactions between growth-limiting and growth-accelerating factors (Briffa et al., 1998; Vaganov et al., 1999). Kharuk et al. (2006) found that the radial increment of larch strongly depends on summer temperatures and the amount of precipitation in both summer and winter. In 2010 a strong heat wave affected the central part of European Russia (with a summer temperature anomaly of $+3{ }^{\circ} \mathrm{C}$ over an area of $\sim 200 \mathrm{Mha}$ ) that decreased seasonal NPP about half (Bastos et al., 2014). In general, besides increased temperature and related drought stress (Barber et al., 2000; Dulamsuren et al., 2013; McDowell et al., 2011; Berner et al., 2013), changes in mortality rates and shifts in plant carbon allocation are considered to be the prime causes of browning (McDowell, 2011; Zhang et al., 2008). Lloyd and Bunn (2007) found a clear distinction between boreal forest of North America and Eurasia. Browning occurs more frequently in dry continental interiors of North America, but with lower than expected frequency in pristine regions of central and eastern Siberia. More specifically, Dulamsuren et al. (2013) found a strong negative effect of enhanced June and July temperature in the previous year on productivity that might be related to an increase in mean evaporative demand in Southern boreal forests of Eastern Kazakhstan. Several 
periods of severe mortality in coniferous forests were observed during the past decades, including e.g. spruce-fir forests in northern European Russia and the Russian Far East, Siberian pine (Pinus sibirica) in Central Siberia (Man'ko and Gladkova, 2001; Shvidenko et al., 2013). Kharuk et al. (2013) suggest that soil water stress is the main factor in forest mortality in the eastern Kuznetzky Alatau Mountains of South Siberia. They detected pine mortality primarily on areas with steep slope; birch and aspen trees in the same area, however, did not show drought stress. Siberian pine is an important forest species covering $\sim 40$ Mha in the region and its decline has great significance for forestry.

However, productivity declines are not a straightforward function of climate but modulated by forest structure and composition. Studies of satellite NDVI data of the boreal forest in North America and Eurasia pointed out that late summer browning which indicates a decrease in vegetation productivity, is associated primarily with densely forested areas (Bunn and Goetz, 2006; Beck et al., 2011; Berner et al., 2013). Specifically, a negative trend of seasonal photosynthetic activity is mostly confined to changing species composition and structure of boreal forests in the continental interior, despite positive trends in photosynthetic activity at the beginning of the vegetation period (Bunn and Goetz, 2006).

Overall, the recent changes in productivity of Russian forests are region- and tree species-specific. Besides obvious impacts of elevated temperatures and season-specific precipitation changes, it is important to note that there are diverse responses and feedbacks driven by air pollution, soil and water contamination, and changes in succession, nutrient availability, and disturbance regime (e.g., Lloyd and Bunn, 2007; Shvidenko et al., 2013).

\subsection{Forest cover changes and vegetation redistribution}

Russia showed the highest forest cover loss globally from 2000 to 2012 (Hansen et al., 2013; Schepaschenko et al., 2015b). Recovery after fires led to large gains in forest cover over the same period, but, due to the slow regrowth dynamics and regional specifics of disturbances, the gains typically occurred in different areas than the losses (Hansen et al., 2013).

However, not only existing forest area is changing but there are also observations of vegetation redistribution. By analyzing Landsat remote sensing data, Kharuk et al. (2006) estimated an advancement of the northern tree line of altitudinal ecotones by 90-300 m over the period 1973-2000 and an increase in the density of larch forests by $\sim 65 \%$. Devi et al. (2008) reported an altitudinal expansion into the formerly tree-free tundra during the last century of about $20-60 \mathrm{~m}$ in altitude, as well as increasing tree ages and higher sapling densities. They attributed this upward shift primarily to extant climatic changes-while highlighting that not only changes in annual values but also changes in seasonality were important. An invasion by more southern conifers was also reported in the zone dominated by larch (Kharuk et al., 2006). Esper and Schweingruber (2004) stressed that winter and summer temperatures are relevant for invasion of trees into the tundra, additionally to sapling survival. Particularly remarkable were the northward shift of the tree line during two warming periods in the 20th century (1930-45 and 1975-99) and southward shifts during a cooling period (1950-70) (Parmesan and Yohe, 2003). Low growing-season temperatures coupled with a short growing season appear to be the major reason for the current tree line distribution.

For the trailing end of forest distribution, Kharuk et al. (2013) described a decline in Russian birch stands in the southeastern Siberian forest-steppe. Kharuk et al. (2010) estimated an increase in the closed vegetated area by $0.8 \%$ per year between 1976 and 2000, as supported by radial tree increments (Esper and Schweingruber, 2004; Kharuk et al., 2006).
Vegetation redistribution affects species composition and forest structure and, thus, may also lead to biodiversity changes. Evidence from warming experiments suggests that climate change may cause a decline in biodiversity in the tundra, as warming promotes increased height and cover of deciduous shrubs and graminoids and, consequently, a decrease in mosses and lichens (Walker et al., 2006). To conclude, there is evidence of changing vegetation distribution and forest cover changes. However, whether range shifts substantiate also depends on non-climatic factors such as migration speed.

\subsection{Observed disturbances}

Disturbances play an important role in Russian forests. Natural and human-induced disturbances (fire, insect/diseases outbreaks, forest harvest operations, snow- and wind-breaks, industrial developments of territories) affect, on average, 20-30 Mha of forest area annually (Shvidenko et al., 2013) affecting succession dynamics, landscape connectivity, productivity and vitality of forest ecosystems, and thus their impacts on the regional and global carbon cycle. Fire is often considered as the single most important forest disturbance in the boreal zone, however the damage by biogenic agents could be of comparable magnitude (FAO, 2012; Shvidenko et al., 2013).

\subsubsection{Fire}

At a first glance, different publications and official fire statistics report different areas affected by fire in Russia (Balshi et al., 2007; Shvidenko et al., 2013). However, time series of major fire extent, based on different satellite sensors and algorithms of assessments with elements of ground corrections, present quite consistent estimates. Shvidenko and Schepaschenko (2013) reported that the

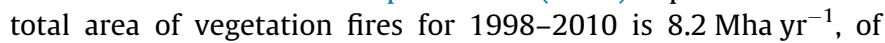

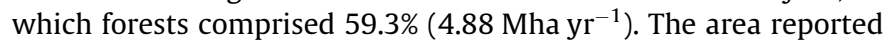
by the global dataset GFED4 for the same period is close to this

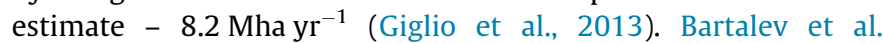

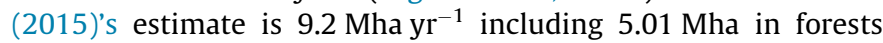
for the period of 2006-2013. Ponomarev and Shvetsov (2013)

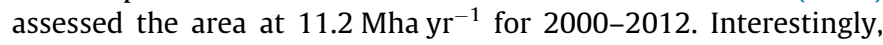
while most fires have occurred in the Central and Eastern parts of the country in the last decades, the heat and drought summer of 2010 has seen an extreme increase of forest fires in European Russia (Fig. 1). Moreover, the structure of fire regimes changes. More than $90 \%$ of burnt area is caused by extra-large fires with an area $>2000$ ha (Ponomarev and Shvetsov (2013)).

During the last 15 years, both the area affected by fire and the severity of fires (defined as the amount of consumed fuel and following impacts on forest ecosystems) have been growing. The

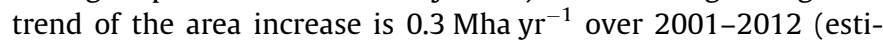
mate based on data presented in Ponomarev and Shvetsov (2013) for Asian Russia). In the 1990s the area was 29\% larger than in the 1980 s and $19 \%$ larger than reported for the 47 -year mean of the period 1960-2007, apparently connected to warmer and drier conditions (Soja et al., 2007). The area of stand-replacement fires

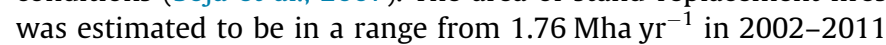

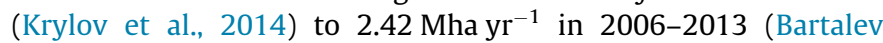
et al., 2015). However, both these studies did not cover the entire period when the post fire dieback occurs.

An inherent feature of fire regimes during recent decades is the increase in frequency, extent and severity of catastrophic megafires. These fires cover tens to hundreds of thousands hectares, lead to degradation of forest ecosystems and depletion of biodiversity (particularly in ecotones of the forest zone), destroy the raw material base of the forest industry, and adversely affect the health of the population (Sukhinin, 2010), they may cause irreversible transformation of forest cover for centuries ("green desertification") and 


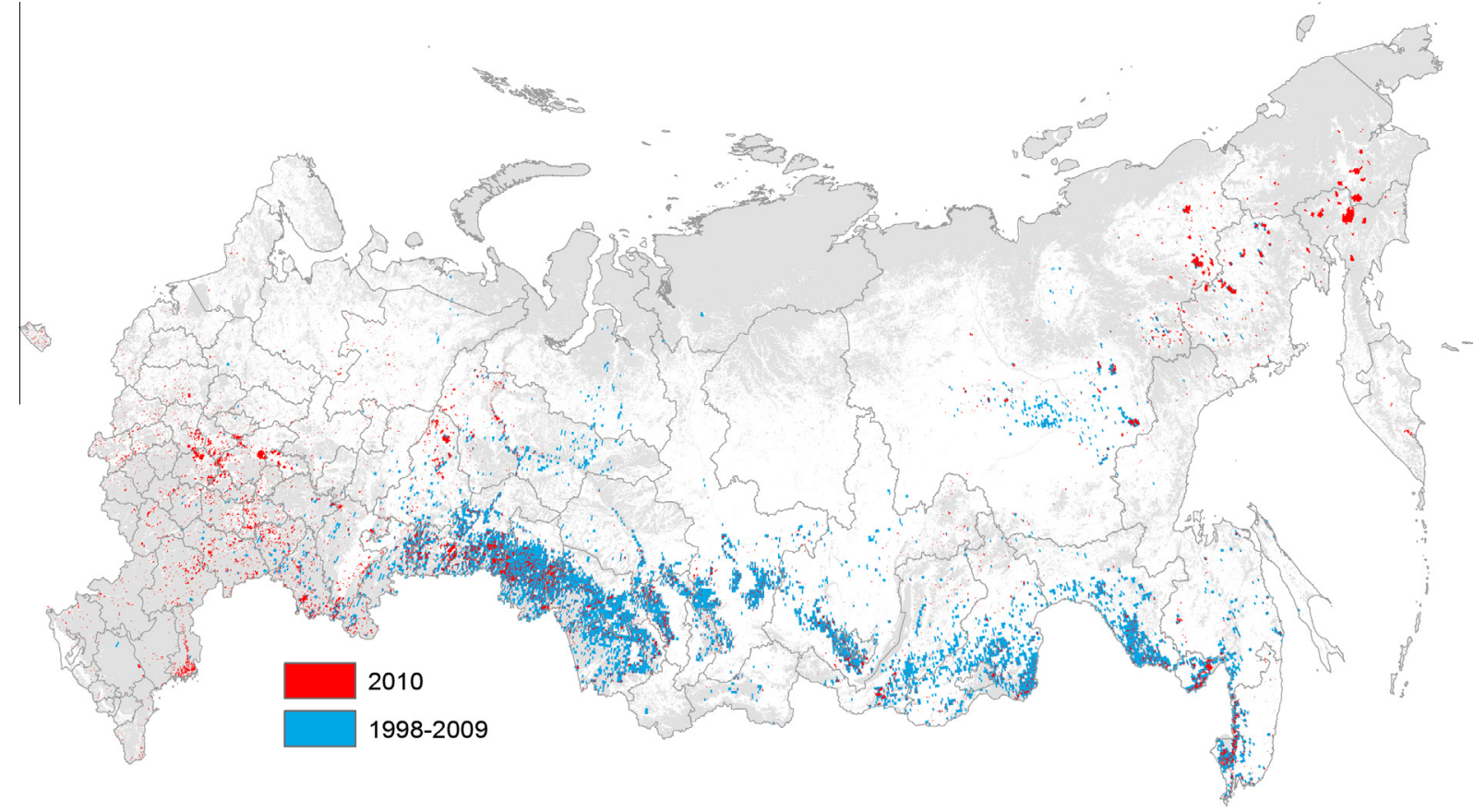

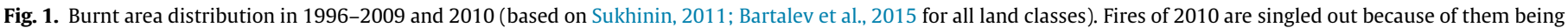
located primarily in the European part which is unusual.

develop specific weather at a scale comparative with the atmospheric pressure systems (i.e., of 20-30 Mha) (Shvidenko and Schepaschenko, 2013).

Fire is a substantial source of carbon emissions. The total amount of carbon contained in consumed fuel by fire on all vegetated land

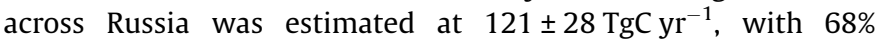
$\left(82 \pm 15{\left.\mathrm{TgC} \mathrm{yr}^{-1}\right)}\right)$ in forests (Shvidenko et al., 2011; Shvidenko and Schepaschenko, 2013). These authors also stressed that postfire dieback is uncertain but may provide carbon emissions to

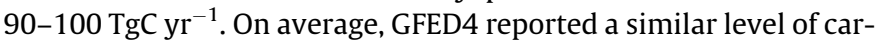
bon emission for the same period, but annual values could be substantially different (Giglio et al., 2013). Estimates from several studies compiled by Balshi et al. (2007) range from $58 \mathrm{TgC} \mathrm{yr}^{-1}$ up to $520 \mathrm{TgC}^{-1}$ for boreal Russia/Siberia for different time periods within the 1971-2002 study period - this suggests a large uncertainty regarding the amount of carbon released through fires. A large part of the uncertainty relates to how burn severity is defined (Balshi et al., 2007). Potapov et al. (2008) have attributed a significant Russian boreal forest loss of $2.9 \%$ to fires between 2000 and 2005 in contrast to the European Russian forest where only $0.1 \%$ forest loss was imputed to fires (Potapov et al., 2011).

There are important feedbacks between fire and climate. A clear positive feedback exists between warming and the escalation of fire regimes: longer dry periods enhance both fire area and severity; in turn, increasing fire emissions temporarily affect the regional climate again increasing fire risk (Shvidenko and Schepaschenko, 2013). Randerson et al. (2006) found that the long-term effects of boreal forest fires on climate warming are ambiguous, since positive feedbacks (enhancing warming) from increasing greenhouse gas emissions may be offset by changes in surface albedo (decreasing warming due to loss of canopy and more snow exposure).

It is important to note that forest fires are also affected by socioeconomic changes. Ivanova et al. (2010) have shown that extant climate change in combination with socioeconomic changes ( $\sim 5$ time decrease of the forest guard and substantial reduction of firefighting funds over the country during the last 15 years) has resulted in an increase in fire severity and area burned (but not fire frequency) in the Tuva region in southern Siberia. Moreover, the large forest fires that occurred in 2010 were due not only to unusual meteorological conditions but also to poor forest governance and management and an increasing area of abandoned farmlands leading to declining numbers of forest managers, forest firefighters, and less-efficient forest protection systems (Isaev and Korovin, 2014 and Flannigan et al., 2009).

\subsubsection{Biogenic and other disturbances}

Forest insects and diseases have affected large areas of forests in Russia. About 13 Mha of East Siberian forest area, representing a loss of 2 billion $\mathrm{m}^{3}$ of growing stock, are reported to have been destroyed by the Siberian silk moth from 1880 to 1969 (Shvidenko et al., 2013). An outbreak of this insect heavily damaged $>1$ Mha in the mid1990s; the next one in 2000-2001 affected an area $>10$ Mha in a larch forest in the north where wide distribution of this insect has never been observed before (Shvidenko et al., 2013). Due to official statistics the area affected by biogenic agents in Russian forests has

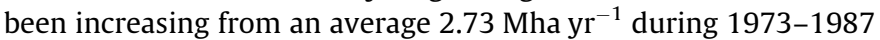
to an average $5.48 \mathrm{Mha} \mathrm{yr}^{-1}$ during 1998-2010 (Isaev, 1991; FAFMRF, 2011). A number of studies also pointed out that a warmer and drier climate would induce large-scale outbreaks of the most dangerous defoliators (e.g., Pleshanov, 1982; Baranchikov et al., 2011). While there is ample evidence for important impacts of forest insects and diseases, there are to our knowledge no studies for the Russian boreal establishing clear links between climate change and disturbances from insects and diseases.

Other large-scale disturbances, as a rule caused by a complicated combination of biotic and abiotic factors, are reported for different regions of Russia. Large-scale drying of dark coniferous forests was observed in the vast territories of the Far East, the mountains of Central Siberia and the European North during the last decades (Shvidenko et al., 2013). Water stress, different anthropogenic impacts and decreased resilience of forests seem to be among the major drivers of this process leading to mortality, which is often ultimately caused by secondary pests (e.g., bark 
beetles, carpenter moths) or root pathogens (like agaric honey, pine fungus, etc.) (e.g., Pavlov and Zykalov, 2014).

\section{Carbon balance}

The forests of the Russian Federation are of great importance for the global carbon cycle. Changes in permafrost dynamics, soil-vegetation carbon dynamics, and vegetation distribution could cause long-term changes in the biosphere at high latitudes with implications for the climate system.

\subsection{Carbon pools}

Live biomass (LB) stored in Russian forests in the 2010s is estimated to be $\sim 35.3 \pm 3.4 \mathrm{PgC}$ using different methods. Pan et al. (2011) found that LB has increased from 1990 to 2007 (see Table 2). Fig. 2 shows spatial distribution of forest LB that was defined using a system of eco-regionally distributed multidimensional models of biomass extension factors and updated forest inventory data.

Tarnocai et al. (2009) have reported a soil carbon store of $331 \mathrm{PgC}$ in permafrost areas of Eurasia in the uppermost meter and another $163 \mathrm{PgC}$ in peats. Pan et al. (2011) and Shvidenko and Nilsson (2003) reported smaller amounts of soil carbon in Russian forests of $152.4 \mathrm{PgC}$ and $130.5 \mathrm{PgC}$, respectively, for the early 1990ies. Schepaschenko et al. (2013) estimated the total soil organic carbon stock in Russian forests at $145 \mathrm{PgC}$ including onground litter ( $8.3 \mathrm{PgC}$ ) and $1 \mathrm{~m}$ of soil below (see Fig. 3 ). The method used combines soil map, in situ measurements, forest inventory data and a number of remote sensing datasets. Soils in forests comprised $45.6 \%$ of carbon of soils of all vegetative lands. The average content of carbon in forests of European and Asian parts were of comparative magnitude $\left(16.2\right.$ and $18.0 \mathrm{kgC} \mathrm{m}^{-2}$, respectively). As it follows from Table 2, different publications report rather consistent estimates of LB stock, while estimates of soil carbon differ substantially. Fig. 3 shows the soil organic carbon distribution of the on-ground litter and the first top soil layer in forest estimated by Schepaschenko et al. (2013).

The data in Table 2 suggest that both LB and soil carbon have increased during the past decades. These trends are consistent when comparing trends found using the same methodology but different years and trends found using different methodologies. Recent studies tend to higher estimates, but also time series

Table 2

Organic carbon in major pools of Russian forest ecosystems ( $\operatorname{PgC})$.

\begin{tabular}{|c|c|c|c|c|c|c|}
\hline References & Year of estimate & Forest area (Mha) & Live biomass $(\mathrm{PgC})$ & Dead wood $(\operatorname{PgC})^{\mathrm{c}}$ & Soil $(\operatorname{PgC})^{b}$ & Total $(\mathrm{PgC})$ \\
\hline Goodale et al. (2002) & 1990 & $821.0^{\mathrm{a}}$ & 33.7 & 8.9 & 139.2 & 181.8 \\
\hline Shvidenko and Nilsson (2003) & 1993 & 763.5 & 32.9 & 8.2 & 130.5 & 171.6 \\
\hline Zavarzin (2007), Chestnykh et al. $(2004,2007)^{\mathrm{d}}$ & 2003 & 776.1 & 34.4 & 5.5 & 125.7 & 165.6 \\
\hline \multirow[t]{3}{*}{ Pan et al. $(2011)^{a}$} & 1990 & 814.3 & 34.9 & 9.4 & 152.4 & 196.7 \\
\hline & 2000 & 821.6 & 36.0 & 10.1 & 155.6 & 201.7 \\
\hline & 2007 & 845.6 & 37.5 & 11.3 & 160.6 & 209.4 \\
\hline Shvidenko and Schepaschenko (2014) & 2007-2009 & 821.4 & 37.5 & 10.3 & 144.5 & 192.3 \\
\hline Thurner et al. (2014) & $2010 s$ & & 31.9 & & & \\
\hline
\end{tabular}

a FAO definition of forests is used (i.e. temporary treeless forest land are included); all other estimates of the table used the Russian national definition.

b Estimates for on-ground organic layer and $1 \mathrm{~m}$ top layer of mineral soil.

c Dead wood includes logs, snags, dead roots, dry branches of living trees and stumps excluding estimate by Zavarzin et al. which included only logs and snugs.

d Zavarzin (2007) - biomass data, Chestnykh et al. (2004, 2007) - soil data; Soil pool - from Schepaschenko et al. (2013).

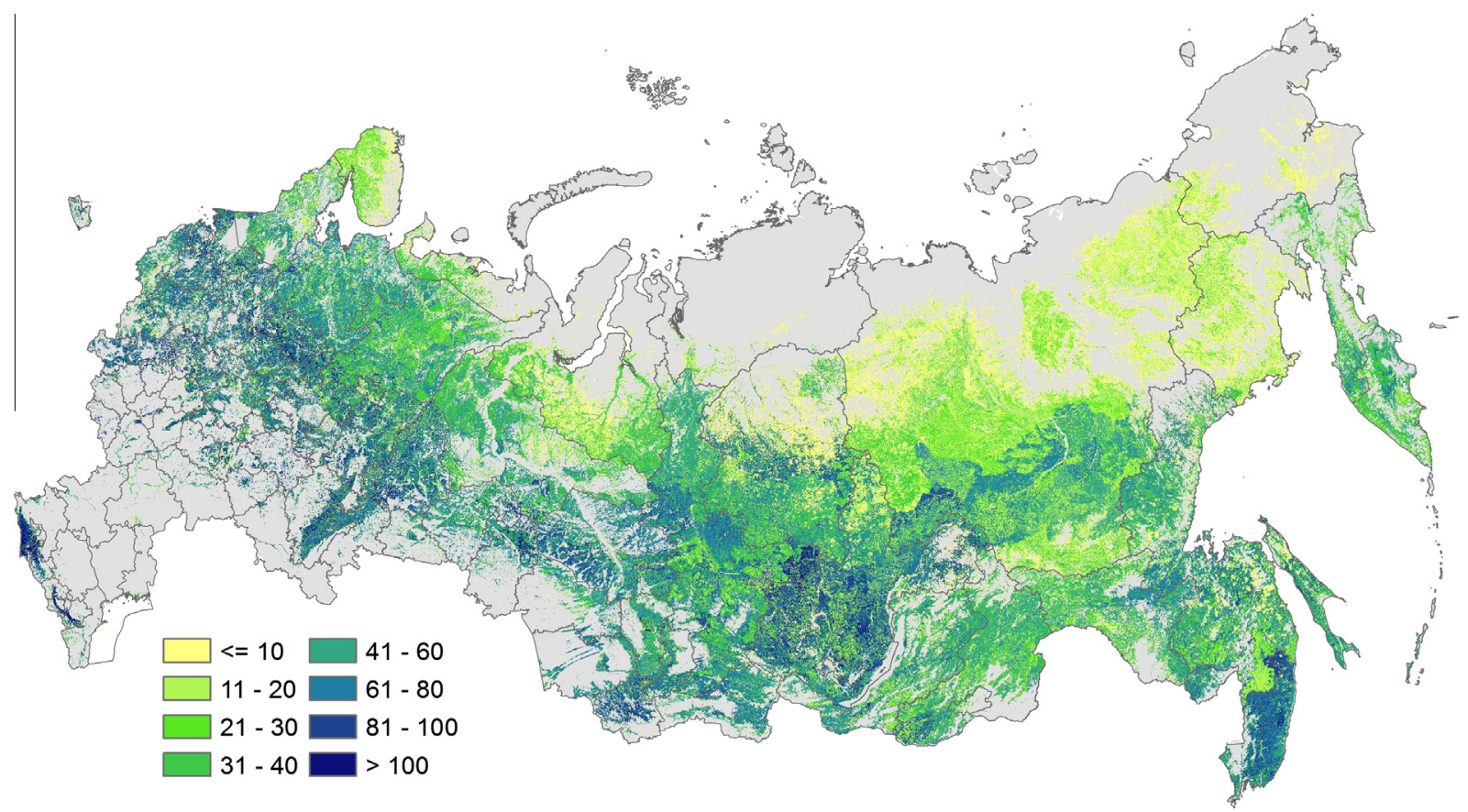

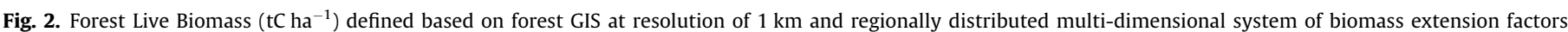

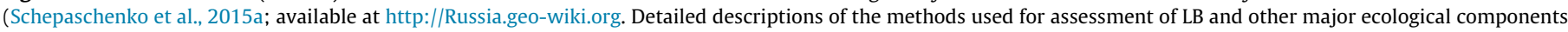
of forest ecosystems, as well as their uncertainties, can be found in Shvidenko et al. (2007b, 2010) and Shvidenko and Schepaschenko (2014). 


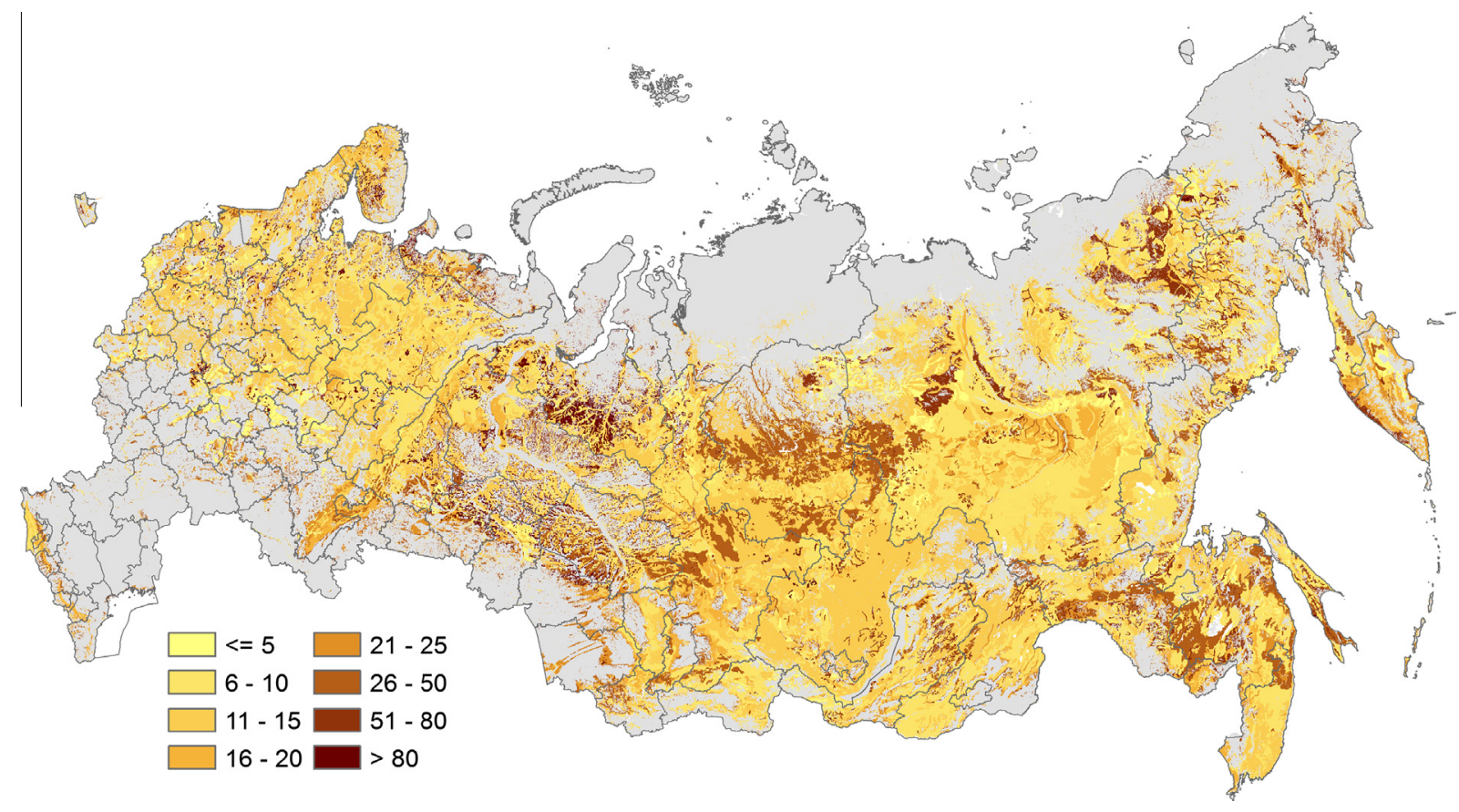

Fig. 3. Soil organic carbon distribution in $\mathrm{kgC} \mathrm{m}^{-2}$ (Schepaschenko et al., 2013).

analyses with the same method show an evident trend to higher carbon storages (Shvidenko and Nilsson, 2003; Pan et al., 2011). However, there seems to be still a high uncertainty to estimated soil carbon in permafrost affected regions.

\subsection{Carbon fluxes}

The pool-based approach of Pan et al. (2011) estimated a consistent carbon sink of $0.40 \mathrm{PgC} \mathrm{yr}^{-1}$ and $0.46 \mathrm{PgC} \mathrm{yr}^{-1}$ in Russian forests from 1990-1999 and 2000-2007, respectively (see Table 3). Myneni et al. (2001) found a contribution of $>40 \%$ to the Northern terrestrial carbon sink of temperate and boreal forests in
1995-1999. Shvidenko and Nilsson $(2002,2003)$ estimate for 19611998 a carbon sink ranging from 0.18 to $0.32 \mathrm{PgC} \mathrm{yr}^{-1}$ based on forest inventories without soil carbon dynamics. Using an unbiased "semi-empirical" method for assessing NPP (Shvidenko et al., 2007b), it has been shown that a new estimate of forest NPP is $\sim 30 \%$ higher than the previous inventory-based estimates (321 vs. $225 \mathrm{gC} \mathrm{m}^{-2} \mathrm{yr}^{-1}$ ). Modifications for assessing heterotrophic soil respiration and the slightly increased forest area resulted in an average carbon sink for 2007-2009 at $0.56 \mathrm{PgC} \mathrm{yr}^{-1}$ (Shvidenko and Schepaschenko, 2014). These estimates are consistent with the results received by inverse modeling (Ciais et al., 2010) and in the range of uncertainties of the sink that was obtained by

Table 3

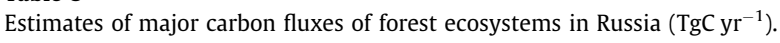

\begin{tabular}{|c|c|c|c|c|c|c|c|c|}
\hline \multirow[t]{2}{*}{ References } & \multirow[t]{2}{*}{ Year of estimate } & \multicolumn{7}{|c|}{ 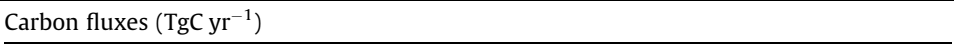 } \\
\hline & & NPP & HR & Fire & Bio & $\mathrm{FP}$ & $\mathrm{H} / \mathrm{L}$ & NBP \\
\hline Shvidenko and Nilsson (2003) & $\begin{array}{l}1961 \\
1998\end{array}$ & $\begin{array}{l}1908^{\mathrm{a}} \\
2034^{\mathrm{a}}\end{array}$ & $\begin{array}{l}1376 \\
1524\end{array}$ & $\begin{array}{l}232^{\mathrm{c}} \\
177^{\mathrm{c}}\end{array}$ & & & $\begin{array}{l}38 \\
40\end{array}$ & $\begin{array}{l}-262 \\
-293\end{array}$ \\
\hline Zamolodchikov et al. $(2011)^{\mathrm{g}}$ & $\begin{array}{l}1988 \\
2008\end{array}$ & $\begin{array}{l}353^{g} \\
397^{g}\end{array}$ & & $\begin{array}{c}150^{\mathrm{g}} \\
96^{\mathrm{g}}\end{array}$ & & $\begin{array}{c}123^{g} \\
61^{g}\end{array}$ & & $\begin{array}{c}-80 \\
-239\end{array}$ \\
\hline Dolman et al. (2012) & $\begin{array}{c}2009 \\
1992-2008\end{array}$ & $2610.2^{\mathrm{b}}$ & 1805.7 & 55.5 & 50.8 & 34.7 & 37.3 & $\begin{array}{l}-626 \pm 161^{d} \\
-680 \pm 246^{e}\end{array}$ \\
\hline $\begin{array}{l}\text { Shvidenko and Schepaschenko (2013) } \\
\text { Balshi et al. (2007) } \\
\text { Shvidenko et al. (2011) }\end{array}$ & $\begin{array}{l}\text { Average for 2007-2009 } \\
\text { Average 1996-2002 } \\
\text { Average 1998-2010 }\end{array}$ & $2610.0^{\mathrm{b}}$ & 1862.5 & $\begin{array}{c}75.3 \\
180.1 \\
121.0^{\mathrm{c}}\end{array}$ & 50.6 & 42.6 & 33.8 & $\begin{array}{c}-546 \pm 120 \\
-280.2^{\mathrm{f}}\end{array}$ \\
\hline Pan et al. (2011) & $\begin{array}{l}\text { Average 1990-1999 } \\
\text { Average 2000-2007 }\end{array}$ & & & & & & & $\begin{array}{l}-401 \pm 101 \\
-463 \pm 116\end{array}$ \\
\hline
\end{tabular}

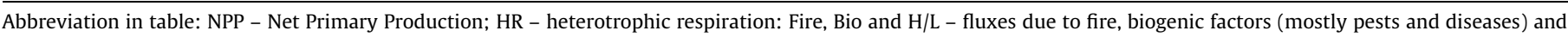
lateral fluxes to hydrosphere and biosphere, respectively, NBP - Net Biome Production; negative values represent carbon sequestered by terrestrial ecosystems.

a NPP was estimated as up-scaled results of measurements based on measurements in situ.

b NPP was estimated by the method described in Shvidenko et al. (2007b).

c Emissions due to disturbances were reported all together.

d Estimated by landscape-ecosystem approach for 2009; the error is indicated for CI 0.9 .

e Estimated by inverse modeling, 12 different inverse schemes, for different parts of the indicated period; 1 standard deviation between different inverse schemes is indicated as the error.

${ }^{\mathrm{f}}$ NBP estimated by simulating the carbon balance with a DGVM.

g Results are mostly based on official statistics; yearly change of carbon pool of LB, CWD, on-ground organic layer and $20 \mathrm{~cm}$ upper layer of soil is indicated in column NBP; FP column contains the reported losses from fire and "other natural disturbances". 


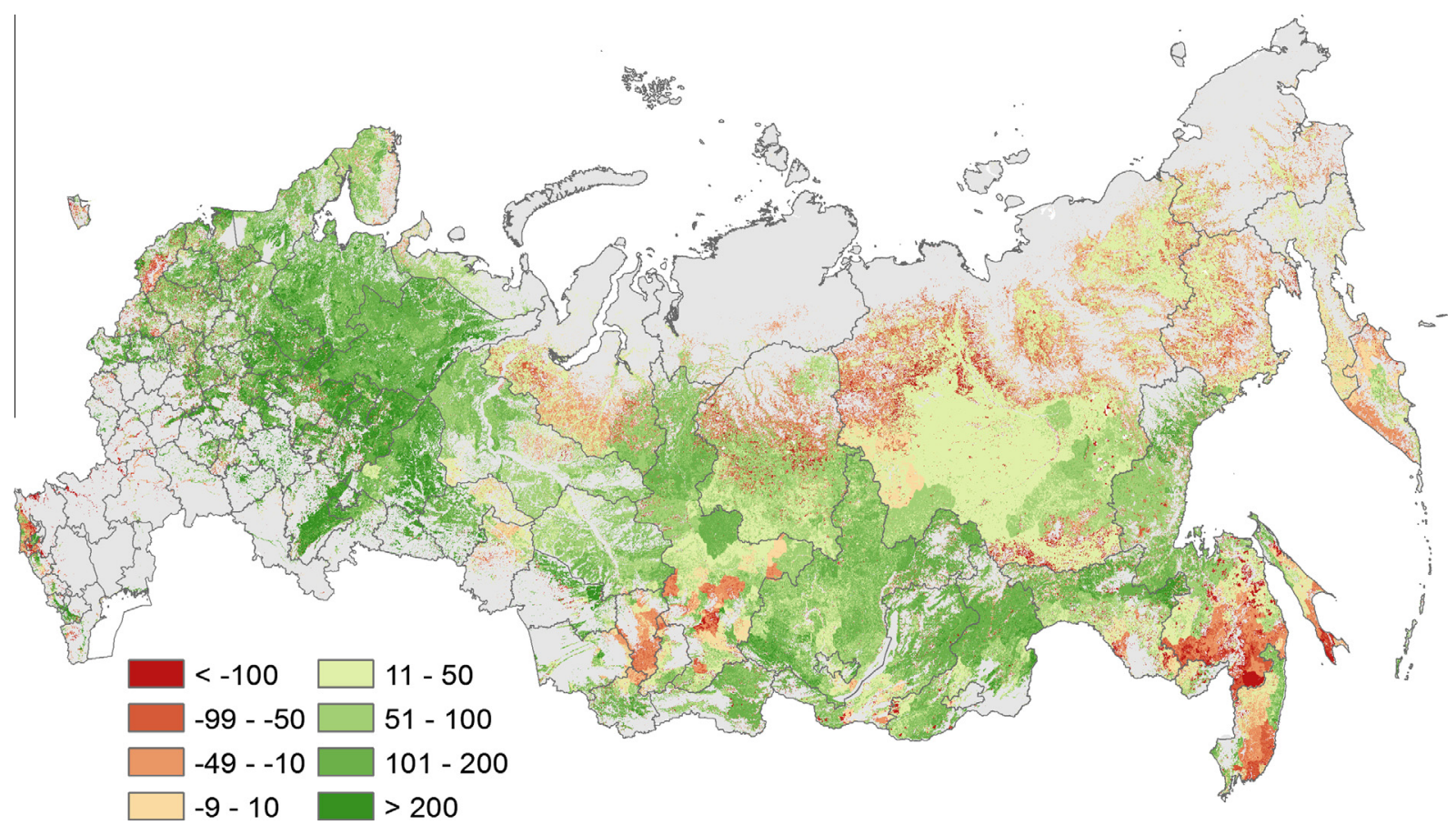

Fig. 4. Net ecosystem carbon budget $\left(\mathrm{gC} \mathrm{m}^{-2}\right)$; negative values indicate a carbon source, positive values a carbon sink (Shvidenko and Schepaschenko, 2014).

upscaling eddy covariance data (Dolman et al., 2012). They

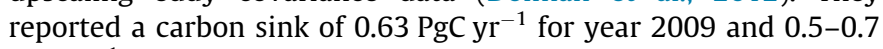
PgC $\mathrm{yr}^{-1}$ from 1998 to 2008.

Kurganova et al. (2010) showed that the re-vegetation of aban-

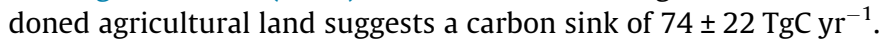
Fig. 4 shows the balance of ecosystem carbon gains and losses of the Russians ecosystem. It indicates that great areas of Russia are a net carbon sink, but also that the northern regions are mostly carbon sources.

Balshi et al. (2007) found conflicting estimates of mean annual changes in carbon storage for Eurasia north of $45^{\circ} \mathrm{N}$ for the period 1996-2002. Using a process-based ecosystem model, they simulated either a sink of $0.28 \mathrm{PgC} \mathrm{yr}^{-1}$ with $\mathrm{CO}_{2}$ fertilization or a source of $0.029 \mathrm{TgC} \mathrm{yr}^{-1}$ without $\mathrm{CO}_{2}$ fertilization. This large range in reported values reflects whether both vegetation and soil carbon are considered or just vegetation carbon, and whether or not disturbances are taken into account as well as uncertainties in process understanding (Balshi et al., 2007). Comparing these results with the inventory approaches, simulations by Balshi et al. (2007) suggest that $\mathrm{CO}_{2}$ fertilization plays an important role in that area and confirm that the future carbon budget can only be explained by taking $\mathrm{CO}_{2}$ fertilization into account.

\section{How might projected future climate change impact Russia's boreal forest?}

This section synthesizes projections of how future climate change will affect Russia's forests in terms of carbon balance and their determining processes as vegetation distribution, disturbances, forest structure and productivity. Using an aggregate metric of biogeochemical and vegetation structural changes and a large range of Dynamic Global Vegetation Model and climate model projections, Warszawski et al. (2013) and Ostberg et al. (2013) found that the boreal forests are at particular risk of changes in the type and distribution of vegetation, carbon pools, and carbon and water fluxes. Many individual processes underlie such changes. Key features are that climate change in interaction with vegetation shifts and fires has the potential to turn the Eurasian carbon sink into a source by 2100 (Kicklighter et al., 2014); that increased temperatures stimulate photosynthesis and productivity (e.g. Magnani et al., 2007; Myneni et al., 1997, 2001); and that future warming could promote plant growth and forest expansion along the Russian Arctic tree line if water availability will remain sufficient (Devi et al., 2008; MacDonald et al., 2008; Berner et al., 2013). Continued warming may offset the benefits of an earlier spring onset and a delayed end of the growing season.

However, the amount of precipitation is small in major continental regions of Central Siberia and here larch forests on continuous permafrost are dominating and form a specific coupled system with permafrost: thawing of permafrost delivers a minimal amount of water for survival of larch ecosystems during dry summer periods (Osawa et al., 2010). Thawing of permafrost may increase water stress and impact resilience of these forests. Already observed permafrost thawing is most pronounced within the discontinuous permafrost zone but is also reported in the continuous permafrost zone (Romanovsky et al., 2010).

\subsection{Vegetation redistribution}

Study results from eastern Eurasia suggest that only modest climate change (with global warming by no more than $2{ }^{\circ} \mathrm{C}$ ) is tolerable to maintain current forest structure and biomass (Shuman et al., 2011; Tchebakova et al., 2009; Zhang et al., 2009, 2011). Above this level, potential changes include permafrost thawing and changes in forest structure whereby broad-leaved deciduous trees could increase their spread over Eastern Eurasia and coniferous area could decrease (Lucht et al., 2006; Schaphoff et al., 2013; Zhang et al., 2009). In a study of larch forests in the region, Zhang et al. (2011) found that such forests could not be sustained under warming of more than $2{ }^{\circ} \mathrm{C}$.

For the whole of the Eurasian continent, Kicklighter et al. (2014) projected that biomes will shift northward as a consequence of climate change, with boreal forest encroaching into the northern tundra zone, temperate forests encroaching into the present boreal 
zone, and steppes encroaching into temperate forests. This would result in a reduction in the boreal forest area by $19 \%$ and an increase in the temperate forest area by $258 \%$ under a businessas-usual climate scenario; in a low-carbon scenario, boreal forest area would decrease by $2 \%$ and temperate forest area increase by $140 \%$, respectively. This would lead to a $7 \%$ net gain, and a $12 \%$ gain in forest area, respectively (Kicklighter et al., 2014).

Several studies using a bioclimatic model support that vegetation zones will shift northward under climate change (Tchebakova et al., 2009, 2011; Tchebakova and Parfenova, 2012). Tchebakova et al. (2009) showed that, for Siberia, changes in vegetation will start as early as the 2020s under all climate change scenarios. Vegetation shifts are projected to remain moderate at $3{ }^{\circ} \mathrm{C}$ warming, but are expected to be substantial for $4{ }^{\circ} \mathrm{C}$ global mean temperature increase. Forest-steppe and steppe ecosystems are predicted to become dominant across large areas of the Siberian tundra (Schaphoff et al., 2006; Tchebakova et al., 2009). However, past dispersal rates (Udra, 1988; King \& Herstrom, 1997) have been shown to be too slow for projected future vegetation shifts to substantiate. While a significant increase in $\mathrm{CO}_{2}$ concentration might lead to early maturation of trees and in increase in their fecundity (LaDeau and Clark, 2001), this cannot change the rate of natural forest migration at the level which would compensate the rate of the bioclimatic zone shifting. Overall, although it is unclear how much dispersal rates may accelerate under climate change, it seems likely that the potential loss or decline of the southern ecotone of the Russian forest zone will not be compensated by increased forest area beyond the current northern tree line.

Changes in vegetation distribution are likely to feed back to the climate. Enhanced warming of the relatively dark forest (as compared to other vegetation) results in an elevated sensible heat flux. Northward movement of the boreal forest, with its relatively low albedo and the resulting replacement of tundra characterized by higher albedo can potentially cause a significant increase in regional and global temperatures (Foley et al., 2003). This climate forcing could have an effect of $25.9 \mathrm{~W} \mathrm{~m}^{-2}$ (Chapin et al., 2005). Such a shift could also increase carbon storage and could cause feedbacks to the climate system by the same magnitude (Field et al., 2007).

\subsection{Changes in disturbances}

A number of studies on modeling the future fire regimes (e.g., Mokhov et al., 2006; Malevsky-Malevich et al., 2008; Shvidenko and Schepaschenko, 2013) predict that the area suffering from maximal fire danger would double by end of this century; share of stand-replacing fires will increase; and post-fire regeneration processes will be slower. However, geographical distribution of that will be heterogeneous being mostly dependent on weather variability. Almost all of these studies do not consider the impacts of thawing permafrost on hydrological regimes in high latitudes.

Projected climate changes in the boreal zone could increase the frequency and intensity of pest outbreaks. Studies of the Canadian boreal forest show that insect disturbances can turn the affected areas from a carbon sink into a carbon source (Kurz et al., 2008). It is important to note that there are considerably more studies on the effects of forest fires than on pests and diseases. What is clear, however, is that climate change will lead to northward shifts and longer and warmer summer seasons beneficial for the growth and reproduction of forest insects (Bale et al., 2002).

There are very few studies which attempted at a system consideration of future trajectories of Russian forests. Gustafson et al. (2010, 2011) applied the Landscape Succession and Disturbances Model Landis-II combined with a physiological model PnET-II which includes impacts of climate, $\mathrm{CO}_{2}$ fertilization, disturbances (fire, insects) and management options to a forest area in the transition zone between middle and southern taiga near Lake Baikal. The most interesting result of this study is that the major parameters of future forest cover (after 100 years and later) appeared to be more dependent on forest management and dangerous insect outbreaks (mostly Siberian silk moth) than on climate change itself and on future fire regimes. Unfortunately, due to high resolution of the model $(100 \mathrm{~m})$ the reported results were presented for a limited area $(400,000 \mathrm{ha})$ that does not allow for conclusions over large geographic domains.

\subsection{Forest productivity and carbon balance}

Projections of carbon stock changes in the boreal forest ecosystems under climate change are uncertain. Simulations show that, as a result of vegetation shifts, the potential carbon gains from the expansion of boreal forests in the north are likely to be offset by losses in the south (Friend et al., 2014; Schaphoff et al., 2013). Furthermore, increases in tree growth from climate warming may be limited by decreased soil fertility in northern and eastern regions (Lawrence et al., 2005). For a forest area in the Kostroma region $450 \mathrm{~km}$ northeast of Moscow, Shanin et al. (2011) projected an increase in carbon stock in trees from $125 \mathrm{tha}^{-1}$ to $150 \mathrm{t} \mathrm{ha}^{-1}$ for $4{ }^{\circ} \mathrm{C}$ global mean temperature increase; this implies strong regional warming of $7.2^{\circ} \mathrm{C}$ by 2100 . The productivity of the stands was projected to increase as well due to the enhanced availability of nitrogen in the soil. However, soil and deadwood carbon stocks were projected to decrease under this climate change scenario (98-99 tons ha ${ }^{-1}$ without vs. 33-35 tons ha ${ }^{-1}$ with climate change). It is important to note that several key climate change effects, including heat stress and $\mathrm{CO}_{2}$ fertilization, were not considered in this study. Furthermore, in those simulations that included the effect of fire, the climate change-induced increase in carbon stock was offset by fires of higher intensity (Shanin et al., 2011). Recent estimate of heterotrophic respiration in Russian forest ecosystems and spatial distribution of the ratio of NPP to heterotrophic respiration (Mukhortova et al., 2015) allow to suppose that the rate of changing of heterotrophic respiration might be higher than this of NPP.

Permafrost is projected to be highly vulnerable to warming, and thawing is projected to be very pronounced (Koven et al., 2011; Schaefer et al., 2011; Schaphoff et al., 2013). Koven et al. (2011) and Schaphoff et al. (2013) stressed that enhanced plant productivity could increase biomass input at different soil depths which can balance out carbon release due to permafrost thawing until the late 21st century. The magnitude of this effect, however, strongly depends on the warming level. Schaefer et al. (2011) estimated a carbon stock loss by $190 \pm 64 \mathrm{PgC}$ by 2200 . Anisimov (2007) estimated that methane emissions from melting permafrost might increase by $20-30 \%$ due to a global mean temperature rise of $2 \mathrm{C}$, congruent with an enhanced permafrost thawing rate of $10-15 \%$ over Russia for the mid-21st century. These fluxes mostly originate in the West Siberian wetlands.

Anisimov and Reneva (2006) projected a reduction in the permafrost area, down to 76-81 percent of the present day value by 2080. Furthermore, simulations by Schaphoff et al. (2013) and Schaefer et al. (2011) showed that, due to inertia in the climate system, carbon release from permafrost thawing will continue for centuries even if warming ceases at some level.

Modell projections of forest ecosystem change in response to anthropogenic climate changes are dominated by plant physiological $\mathrm{CO}_{2}$ effects (Friend et al., 2014). Moreover, the stability of ecosystems in response to extreme events such as flooding and drought is unpredictable (Bale et al., 2002). The interplay of disturbances (e.g. fire) and vegetation shifts, as well as the effects of climatic feedbacks, determine the future of the carbon stored in and the goods and services provided by boreal forests. 


\section{Can we identify Russia's boreal forest as a potential tipping point?}

Lenton et al. (2008) identified the boreal forest as a tipping element in the earth's system. They argued that, under an estimated $3-5{ }^{\circ} \mathrm{C}$ of global warming (that means $7-10^{\circ} \mathrm{C}$ for major part of Russia and up to $12{ }^{\circ} \mathrm{C}$ in some regions), water and peak summer heat stress leading to tree mortality, to increased vulnerability to diseases and fire, and to decreased reproduction rates could lead to a large-scale forest dieback and a transition to open woodlands or grasslands. Analyzing satellite data, Scheffer et al. (2012) suggested that the only possible ecosystem states at the northern edge and at the dry continental southern edge are treeless tundra and steppe. Their study also found a broad intermediate temperature range where treeless ecosystems states coexist with boreal forest (about 75\% tree cover). Tree covers of, respectively, 10\%, 30\%, and $60 \%$ are relatively rare. Scheffer et al. (2012) therefore suggest that these may represent unstable states. Such sparse tree cover occurs especially in continental permafrost-affected areas and on saturated soils. They furthermore suggest that boreal forest may be less resilient than assumed (and thus potentially shift into a sparse woodland or treeless state, e.g. through fire) while tundra may shift abruptly to a more abundant tree cover state. The mechanisms which could explain such unstable states are not clear, however, and uncertainty surrounding these findings is high.

The evidence for a tipping point of the boreal forest is unclear. However, already under current conditions the impacts of climate variability, heat waves and disturbances such as fire and pest outbreaks are substantial-and projected climate change impacts could be both large-scale and disastrous.

\section{Conclusion: the importance of interacting factors}

This review shows that Russia's boreal forests are changing in terms of productivity, forest cover, carbon budget and disturbance regimes and that ongoing climate change is an important driver of these changes (Fig. 5). The far North shows a rather uniform trend toward higher plant productivity and forest cover gain whereas southern locations show more diverse reactions, but with a trend toward decreased productivity and forest cover loss. Together with similar observations from Canada's boreal forest (Price et al., 2013) this means that a huge area of circumboreal forests is affected by climate change.

Future projections suggest that climate change will exacerbate these trends and cause even more substantial changes. Ecotones, from forest to tundra in the north and to steppe in the south, are very vulnerable to climate change. In particular, increases in atmospheric water demand could lead to water stress and higher tree mortality. Changes in species composition toward better adapted tree species may buffer productivity losses, although they will also alter forest composition and structure and hence the forest landscape and its associated uses. Projected climate change will also induce an increase in fire danger and fire intensity while defoliators and other pests and diseases could be stimulated by a warmer and drier climate. Such increased occurrence of disturbances could also affect biodiversity and vegetation distribution, especially in transition zones.

Russia also contains an extensive area of forested permafrost. Observed changes in carbon sequestration and plant productivity here are already among the largest and they could accelerate as a result of permafrost thawing. This has the potential to affect the

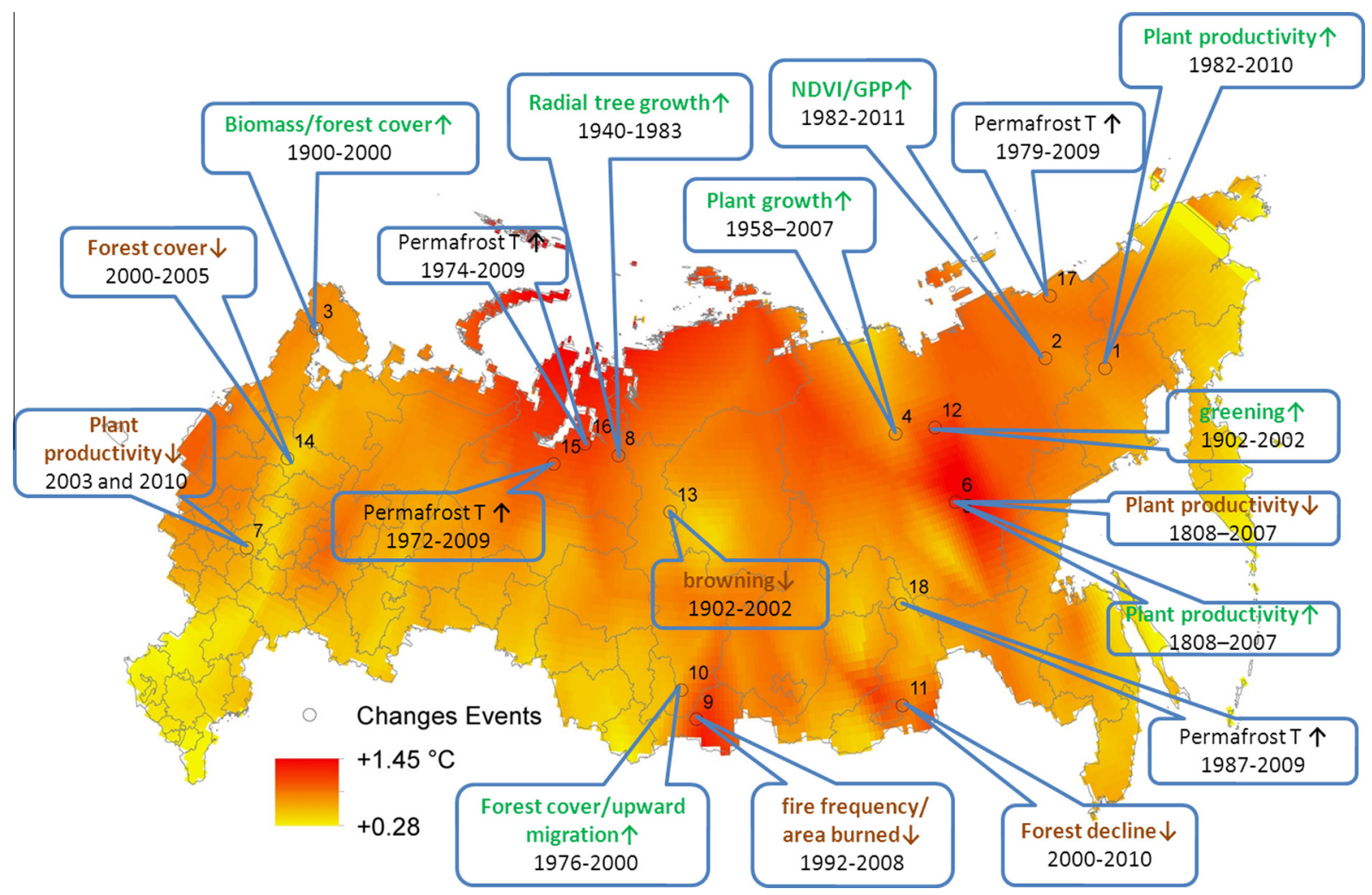

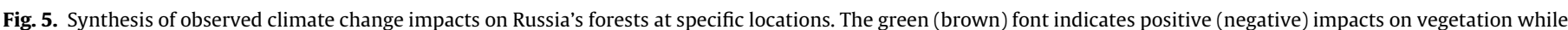

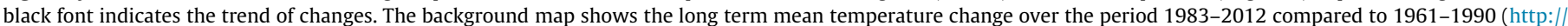

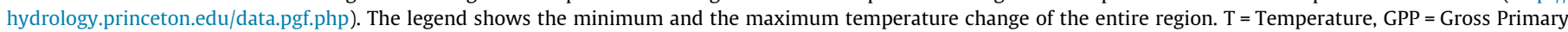

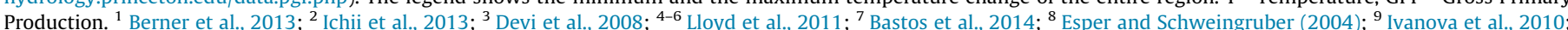

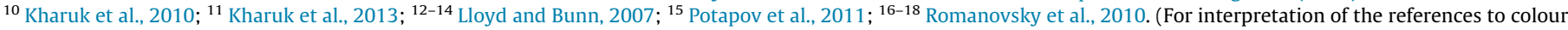
in this figure legend, the reader is referred to the web version of this article.) 
hydrological regimes of vast territories beyond the changes in hydrology expected from precipitation changes alone, and could affect critical carbon, water, and energy fluxes.

The past, present and future impacts of climate change are often superimposed by other environmental and societal changes exacerbating existing and projected challenges. However, we find that the aggregate impacts of synchronous environmental and social changes have hardly been studied, although it is clear that they may strongly affect local, regional, and global forest resource availability, ecosystem functioning, services such as carbon storage and biodiversity support, and even feedback on the global climate system. Future research will need to fill these knowledge gaps to better understand the mitigation potential and to inform the adaptation of Russia's forests to climate change.

\section{Acknowledgments}

This research is a spin-off from the World Bank Project "Turn Down the Heat: Confronting the New Climate Normal" and we are grateful to everybody involved in this activity for making it a success. Christopher Reyer acknowledges financial support from the German Federal Ministry of Education and Research (BMBF, Grant no. 01LS1201A1).

\section{References}

Alexeyev, V.A., Markov, M.V. (Eds.), 2003. Statistical Data on Forest Fund and Change of Productivity of Forests of Russia in the Second Half of XX Century. Forestry Research Institute, Saint-Petersburg, S.-P., p. 271 (in Russian).

Allen, C.D., Makalady, A.K., Checjuini, H., Bachelet, D., McDowell, N., Vennetier, M. Kitzberger, T., Rigling, A., Breshears, D., Hogg (Ted), E.D., Gonzalez, P., Fensham, R., Zhang, Z., Castro, J., Demidova, N., Lim, J.-M., Allard, G., Runing, S.W., Semerzi, A., Cobb, N., 2010. A global overview of drought and heat-induced tree mortality reveals emerging climate change risk for forests. For. Ecol. Manage. 259, 660 684.

Anisimov, O., 2007. Potential feedback of thawing permafrost to the global climate system through methane emission. Environ. Res. Lett. 2 (4), 045016. http://dx. doi.org/10.1088/1748-9326/2/4/045016.

Anisimov, O., Reneva, S., 2006. Permafrost and changing climate: the Russian perspective. Ambio 35 (4), 169-175, http://www.ncbi.nlm.nih.gov/pubmed/ 16944641.

Bale, J.S., Masters, G.J., Hodkinson, I.D., Awmack, C., Bezemer, T.M., Brown, V.K et al., 2002. Herbivory in global climate change research: direct effects of rising temperature on insect herbivores. Glob. Change Biol. 8 (1), 1-16. http://dx.doi. org/10.1046/j.1365-2486.2002.00451.x.

Balshi, M.S., McGuire, a.D., Zhuang, Q. Melillo, J., Kicklighter, D.W., Kasischke, E., et al., 2007. The role of historical fire disturbance in the carbon dynamics of the pan-boreal region: a process-based analysis. J. Geophys. Res. 112 (G2), G02029. http://dx.doi.org/10.1029/2006JG000380.

Baranchikov, Y.N., Kondakov, V.P., Petrenko, E.S., 2011. Siberian moss - a relentless modifier of taiga forest systems in Northern Asia. In: Boral Forests and Needs for Actions. IBFRA, Krasnoyarsk, pp. 105-107.

Barber, V.A., Juday, G.P., Finney, B.P., 2000. Reduced growth of Alaskan white spruce in the twentieth century from temperature-induced drought stress. Nature 405 (6787), 668-673. http://dx.doi.org/10.1038/35015049.

Bartalev, S.A., Stysenko, F.V., Egorov, B.A., Lupyan, E.A., 2015. Satellite estimate of death of Russian forests caused by fire. Forest Sci. (Lesovedenie) 2, 83-94 (in Russian).

Bastos, A., Gouvenia, C.V., Trigo, R.M., 2014. Analysing the spatio-temporal impacts of the 2003 and 2010 extreme heatwaves on plant productivity in Europe. Biogeosciences 11, 3421-3435.

Beck, P., Goetz, S.J., 2012. Corrigendum: satellite observations of high northern latitude vegetation productivity changes between 1982 and 2008: ecological variability and regional differences. Environ. Res. Lett. 7 (2), 029501. http://dx. doi.org/10.1088/1748-9326/7/2/029501.

Beck, P., Juday, G.P., Alix, C., Barber, V.A., Winslow, S.E., Sousa, E.E., et al., 2011. Changes in forest productivity across Alaska consistent with biome shift. Ecol. Lett. 14 (4), 373-379.

Berner, L.T., Beck, P.S.A., Bunn, A.G., Lloyd, A.H., Goetz, S.J., 2011. High-latitude tree growth and satellite vegetation indices: correlations and trends in Russia and Canada (1982-2008). J. Geophys. Res. http://dx.doi.org/10.1029/2010JG001475.

Berner, L.T., Beck, P.S.a., Bunn, A.G., Goetz, S.J., 2013. Plant response to climate change along the forest-tundra ecotone in northeastern Siberia. Glob. Change Biol. 19 (11), 3449-3462. http://dx.doi.org/10.1111/gcb.12304.

Betts, R.A., 2000. Offset of the potential carbon sink from boreal forestation by decreases in surface albedo. Nature 408 (6809), 187-190. http://dx.doi.org/ $10.1038 / 35041545$
Boisvenue, C., Running, S.W., 2006. Impacts of climate change on natural forest productivity - evidence since the middle of the 20th century. Global Change Biol. 12, 862-882. http://dx.doi.org/10.1111/j.1365-2486.2006.01134.x.

Bonan, G.B., 2008. Forests and climate change: forcings, feedbacks, and the climate benefits of forests. Science (New York, N.Y.) 320 (5882), 1444-1449. http://dx. doi.org/10.1126/science.1155121.

Briffa, K.R., Schweingruber, F.H., Jones, P.D., Osborn, T.J., Shiyatov, S.G., Vaganov, E. A., 1998. Reduced sensitivity of recent tree-growth to temperature at high northern latitudes. Nature 391, 678-682.

Bunn, A.G., Goetz, S.J., 2006. Trends in satellite-observed circumpolar photosynthetic activity from 1982 to 2003: the influence of seasonality, cover type, and vegetation density. Earth Interact. 10 (12), 1-19. http://dx.doi.org/ 10.1175/EI190.1.

Chapin, F.S., Sturm, M., Serreze, M.C., McFadden, J.P., Key, J.R., Lloyd, a.H., et al., 2005. Role of land-surface changes in arctic summer warming. Science (New York, N. Y.) 310 (5748), 657-660. http://dx.doi.org/10.1126/science.1117368.

Chestnykh, O.V., Zamolodchikov, D.G., Utkin, A.I., 2004. Total reserves of biological carbon and nitrogen in soils of Russian Federation. Lesovedenie (Soil Sci.) (4), 30-42 (in Russian).

Chestnykh, O.V., Lyzhyn, V.A., Kokshrova, A.V., 2007. Carbon reserves in litters of Russian Federation. Lesovedenie (Forest Sci.) (6), 114-121 (in Russian).

Ciais, P., Janssens, I., Shvidenko, A., Wirth, C., Malhi, Y., Grace, J., Schulze, E.D. Heimann, M., Phillips, O., Dolman, A.J., 2005. The potential for rising $\mathrm{CO}_{2}$ to account for the observed uptake of carbon by tropical, temperate, and boreal forest biomes. SEB Exp. Biol. Ser., 109-149

Ciais, P., Canadell, J.G., Luyssaert, S., Chevallier, F., Shvidenko, A., Poussi, Z., Jonas, M., Peylin, P., King, A.W., Schulze, E.-D., Piao, S.L., Rodenbeck, C., Pters, W., Breon, F. M., 2010. Can we reconcile atmospheric estimates of Northern terrestrial carbon sink with land-based accounting? Curr. Opin. Environ. Sustain. 2, 225230. http://dx.doi.org/10.1016/j.cosust.2010.06.008.

De Jong, R., de Bruin, S., de Wit, A., Schaepman, M.E., Dent, D.L., 2011. Analysis of monotonic greening and browning trends from global NDVI time-series. Rem. Sens. Environ. 115 (2), 692-702, <http://www.sciencedirect.com/science/ article/pii/S0034425710003160>.

Devi, N., Hagedorn, F., Moiseev, P., Bugmann, H., Shiyatov, S., Mazepa, V., Rigling, A., 2008. Expanding forests and changing growth forms of Siberian larch at the Polar Urals treeline during the 20th century. Glob. Change Biol. 14 (7), 15811591. http://dx.doi.org/10.1111/j.1365-2486.2008.01583.x.

Dolman, A.J., Shvidenko, A., Schepaschenko, D., Ciais, P., Tchebakova, N., Chen, T., et al., 2012. An estimate of the terrestrial carbon budget of Russia using inventory-based, eddy covariance and inversion methods. Biogeosciences 9 (12), 5323-5340. http://dx.doi.org/10.5194/bg-9-5323-2012.

Dulamsuren, C., Wommelsdorf, T., Zhao, F., Xue, Y., Zhumadilov, B.Z., Leuschner, C. Hauck, M., 2013. Increased summer temperatures reduce the growth and regeneration of Larix sibirica in southern boreal forests of eastern Kazakhstan. Ecosystems 16 (8), 1536-1549. http://dx.doi.org/10.1007/s10021-013-9700-1.

Esper, J., Schweingruber, F.H., 2004. Large-scale treeline changes recorded in Siberia. Geophys. Res. Lett. 31 (6), L06202. http://dx.doi.org/10.1029/2003GL019178.

FAFMRF, 2011. Report on Forest Pathological Monitoring in Forests of Russia in 2010. Federal Agency of Forest Management of Russian Federation, Moscow, p. 88 (in Russian).

FAO, 2012. Russian Federation Forest Sector Outlook Study to 2030. Food and Agriculture Organisation of the United Nations, Rome, Italy.

Field, C.B., Lobell, D.B., Peters, H.a., Chiariello, N.R., 2007. Feedbacks of terrestrial ecosystems to climate change. Annu. Rev. Environ. Resour. 32 (1), 1-29. http:// dx.doi.org/10.1146/annurev.energy.32.053006.141119.

Flannigan, M., Stocks, B., Turetsky, M., Wotton, M., 2009. Impacts of climate change on fire activity and fire management in the circumboreal forest. Glob. Change Biol. 15 (3), 549-560.

Foley, J.A., Costa, M.H., Delire, C., Ramankutty, N., Snyder, P., 2003. Green surprise? How terrestrial ecosystems could affect earth's climate. Front. Ecol. Environ. 1 (1), 38-44.

Friend, A.D., Lucht, W., Rademacher, T.T., Keribin, R., Betts, R., Cadule, P., et al., 2014. Carbon residence time dominates uncertainty in terrestrial vegetation responses to future climate and atmospheric $\mathrm{CO}_{2}$. Proc. Natl. Acad. Sci. USA 111 (9), 3280-3285. http://dx.doi.org/10.1073/pnas.1222477110.

Gauthier, S., Bernier, P., Kuuluvainen, T., Shvidenko, A.Z., Schepaschenko, D.G., 2015. Boreal forest health and global change. Science 819-822. http://dx.doi.org/ 10.1126/science.aaa9092.

Ge, Z.M., Kellomäki, S., Peltola, H., Zhou, X., Väisänen, H., Strandman, H., 2013. Impacts of climate change on primary production and carbon sequestration of boreal Norway spruce forests: finland as a model. Climatic change 118 (2), 259-273.

Giglio, L., Randerson, J.T., van der Werf, G.R., 2013. Analysis of daily, monthly, and annual burned area using the fourth-generation global fire emissions database (GFED4). J. Geophys. Res. Biogeosci. 118, 317-328.

Goetz, S.J., Mack, M.C., Gurney, K.R., Randerson, J.T., Houghton, R.A., 2007. Ecosystem responses to recent climate change and fire disturbance at northern high latitudes: observations and model results contrasting northern Eurasia and North America. Environ. Res. Lett. http://dx.doi.org/10.1088/17489326/2/4/045031.

Goodale, C.L., Apps, M.J., Birdsey, R.A., Field, C.B., Heath, L.S., Houghton, R.A., Jenkins, J.C., Kohlmaier, G.H., Kurz, W., Liu, S., Nabuurs, G.-J., Nilsson, S., Shvidenko, A. 2002. Forest carbon sink in the Northern Hemisphere. Ecol. Appl. 12 (3), $891-$ 899. 
Gustafson, E.J., Shvidenko, A.Z., Sturtevant, B.S., Sheller, R.M., 2010. Predicting global change effects on forest biomass and composition in south-central Siberia. Ecol. Appl. 20 (3), 700-715.

Gustafson, E.J., Shvidenko, A.Z., Sheller, R.M., 2011. Effectiveness of forest management strategy to mitigate effects of global change in south-central Siberia. Can. J. For. Res. 41, 1405-1421.

Hansen, J., Sato, M., Ruedy, R., Lo, K., Lea, D.W., Medina-Elizade, M., 2006. Global temperature change. Proc. Natl. Acad. Sci. USA 103 (39), 14288-14293. http:// dx.doi.org/10.1073/pnas.0606291103.

Hansen, J., Ruedy, R., Sato, M., Lo, K., 2010. Global surface temperature change. Rev. Geophys. 48, 1-29.

Hansen, M.C., Potapov, P.V., Moore, R., Hancher, M., Turubanova, S.a., Tyukavina, A., et al., 2013. High-resolution global maps of 21st-century forest cover change. Science (New York, N.Y.) 342 (6160), 850-853. http://dx.doi.org/ 10.1126/science.1244693.

Ichii, K., Kondo, M., Okabe, Y., Ueyama, M., Kobayashi, H., Lee, S.-J., et al., 2013. Recent changes in terrestrial gross primary productivity in Asia from 1982 to 2011. Rem. Sens. 5 (11), 6043-6062. http://dx.doi.org/10.3390/rs5116043.

Isaev A.S. (Ed.), 1991. Forecast of use and reproduction of forest resources by economic regions of the USSR by 2010. Academy of Sciences of the USSR and State Committee of the USSR on Forests, Moscow, vol. 1, p. 508 (in Russian).

Isaev, A.S., Korovin, G.N., 2014. Forests as a national treasure of Russia. Contemp. Probl. Ecol. 6 (7), 677-682. http://dx.doi.org/10.1134/S1995425513070056.

Ivanova, G.A., Ivanov, V.A., Kukavskaya, E.A., Soja, A.J., 2010. The frequency of forest fires in Scots pine stands of Tuva, Russia. Environ. Res. Lett. 5 (1), 015002. http:// dx.doi.org/10.1088/1748-9326/5/1/015002.

Jeong, S.-J., Ho, C.-H., Gim, H.-J., Brown, M.E., 2011. Phenology shifts at start vs. end of growing season in temperate vegetation over the Northern Hemisphere for the period 1982-2008. Glob. Change Biol. 17 (7), 2385-2399, <http:// onlinelibrary.wiley.com/doi/10.1111/j.1365-2486.2011.02397.x/pdf>

Kharuk, V.I., Ranson, K.J., Im, S.T., Naurzbaev, M.M., 2006. Forest-tundra larch forests and climatic trends. Russ. J. Ecol. 37 (5), 291-298. http://dx.doi.org/10.1134/ S1067413606050018.

Kharuk, V.I., Im, S.T., Dvinskaya, M.L., 2010. Forest-tundra ecotone response to climate change in the Western Sayan Mountains, Siberia. Scand. J. For. Res. 25 (3), 224-233. http://dx.doi.org/10.1080/02827581003766959.

Kharuk, V.I., Dvinskaya, M.L., Im, S.T., Ranson, K.J., 2011. The potential impact of $\mathrm{CO}_{2}$ and air temperature increases on krummholz's transformation into arborescent form in the southern Siberian Mountains. Arct. Antarct. Alp. Res. 43 (4), 7-12.

Kharuk, V.I., Im, S.T., Oskorbin, P.A., Petrov, I.A., Ranson, K.J., 2013. Siberian pine decline and mortality in southern siberian mountains. For. Ecol. Manage. 310, 312-320. http://dx.doi.org/10.1016/j.foreco.2013.08.042.

Kharuk, V.I., Kuzmichev, V.V., Im, S.T., Ranson, K.J., 2014. Birch stands growth increase in Western Siberia. Scand. J. For. Res. 29 (5), 421-426.

Kicklighter, D.W., Cai, Y., Zhuang, Q., Parfenova, E.I., Paltsev, S., Sokolov, A.P., Melillo, J.M., Reilly, J.M., Tchebakova, N.M., Lu, X., 2014. Potential influence of climateinduced vegetation shifts on future land use and associated land carbon fluxes in Northern Eurasia. Environ. Res. Lett. 9, 14

King, G.A., Herstrom, A.A., 1997. Holocene tree migration rates objectively determined from fossil pollen data. In: Hantley, B et al. (Eds.), Past and Future Rapid Environmental Changes: the Spatial and Evolutionary Responses of Terrestrial Biota. Springer, pp. 91-101.

Koven, C.D., Ringeval, B., Friedlingstein, P., Ciais, P., Cadule, P., Khvorostyanov, D., et al., 2011. Permafrost carbon-climate feedbacks accelerate global warming. Proc. Natl. Acad. Sci. USA 108 (36), 14769-14774. http://dx.doi.org/10.1073/ pnas.1103910108.

Krylov, A., McCarty, J.I., Potapov, P., Loboda, T., Tykavina, A., Turubanov, S., Hansen, M.C., 2014. Remote sensing estimates of stand-replacement fires in Russia, 2002-2011. Environ. Res. Lett. 9 (10). http://dx.doi.org/10.1088/1748-9326/9/ $10 / 105007$.

Kurganova, I.N., Kudeyarov, V.N., Lopes de Gerenyu, 2010. Updated estimate of carbon balance on Russian territory. Tellus 62B, 497-505.

Kurz, W.A., Stinson, G., Rampley, G.J., Dymond, C.C., Neilson, E.T., 2008. Risk of natural disturbances makes future contribution of Canada's forests to the global carbon cycle highly uncertain. Proc. Natl. Acad. Sci. 105 (5), 1551-1555.

LaDeau, S., Clark, J., 2001. Rising $\mathrm{CO}_{2}$ levels and the fecundity of forest trees. Science 292, 95-98.

Lapenis, A., Shvidenko, A., Shepaschenko, D., Nilsson, S., Aiyyer, A., 2005. Acclimation of Russian forests to recent changes in climate. Glob. Change Biol. 11, 2090-2102. http://dx.doi.org/10.1111/j.1365-2486.2005.01069.x.

Lawrence, G.B., Lapenis, A.G., Berggren, D., Aparin, B.F., Smith, K.T., Shortle, W.C., et al., 2005. Climate dependency of tree growth suppressed by acid deposition effects on soils in northwest Russia. Environ. Sci. Technol. 39 (7), 2004-2010.

Lenton, T.M., Held, H., Kriegler, E., Hall, J.W., Lucht, W., Rahmstorf, S., Schellnhuber, H.J., 2008. Tipping elements in the Earth's climate system. Proc. Natl. Acad. Sci. 105 (6), 1786-1793.

Lloyd, A.H., Bunn, A.G., 2007. Responses of the circumpolar boreal forest to 20th century climate variability. Environ. Res. Lett. 2 (4), 045013. http://dx.doi.org/ 10.1088/1748-9326/2/4/045013.

Lloyd, A.H., Bunn, A.G., Berner, L., 2011. A latitudinal gradient in tree growth response to climate warming in the Siberian taiga. Glob. Change Biol. 17 (5), 1935-1945. http://dx.doi.org/10.1111/j.1365-2486.2010.02360.x.

Lucht, W., Schaphoff, S., Erbrecht, T., Heyder, U., Cramer, W., 2006. Terrestrial vegetation redistribution and carbon balance under climate change. Carbon Balance Manage. 1, 6. http://dx.doi.org/10.1186/1750-0680-1-6.
MacDonald, G.M., Kremenetski, K.V., Beilman, D.W., 2008. Climate change and the northern Russian treeline zone. Philos. Trans. R. Soc. Lond. B Biol. Sci. 363 (1501), 2285-2299. http://dx.doi.org/10.1098/rstb.2007.2200.

Magnani, F., Mencuccini, M., Borghetti, M., Berbigier, P., Berninger, F., Delzon, S., et al., 2007. The human footprint in the carbon cycle of temperate and boreal forests. Nature 447 (7146), 848-850. http://dx.doi.org/10.1038/nature05847.

Malevsky-Malevich, S.P., Molkentin, E.K., Nadyozhina, E.D., Shklyarevich, O.B., 2008 An assessment of potential change in wildfire activity in the Russian boreal forest zone induced by climate warming during the twenty-first century. Climatic Change 86, 463-474.

Malhi, Y., Baldocchi, D.D., Jarvis, P.G., 1999. The carbon balance of tropical, temperate and boreal forests. Plant, Cell Environ. 22, 715-740. http://dx.doi. org/10.1046/j.1365-3040.1999.00453.x.

Man'ko, Y.I., Gladkova, G.A., 2001. Drying of Spruce in the Context of Global Degradation of Dark Coniferous Forest. Dalnauka, Vladivostok, p. 231 (in Russian).

McDowell, N.G., 2011. Mechanisms linking drought, hydraulics, carbon metabolism and vegetation mortality. Plant Physiol. 155 (3), 1051-1059. http://dx.doi.org/ 10.1104/pp.110.170704.

McDowell, N.G., Beerling, D.J., Breshears, D.D., Fisher, R.A., Raffa, K.F., Stitt, M., 2011 The interdependence of mechanisms underlying climate-driven vegetation mortality. Trends Ecol. Evol. 26 (10), 523-532. http://dx.doi.org/10.1016/j. tree.2011.06.003.

Mokhov, I.I., Chernokulsky, A.V., Shkolnik, I.M., 2006. Regional model assessments of fire risks under global climate changes. Dokl. Earth Sci. 411 (9), 1485-1488.

Mukhortova, L., Schepaschenko, D., McCallum, I., Kraxner, F., 2015. Soil contribution to carbon budget of Russian forests. Agric. For. Meteorol. 200, 97-108.

Myneni, R.B., Keeling, C.D., Tucker, C.J., Asrar, G., Nemani, R.R., 1997. Increased plant growth in the northern high latitudes from 1981 to 1991. Nature.

Myneni, R.B., Dong, J., Tucker, C.J., Kaufmann, R.K., Kauppi, P.E., Liski, J., et al., 2001. A large carbon sink in the woody biomass of Northern forests. Proc. Natl. Acad. Sci. USA 98 (26), 14784-14789. http://dx.doi.org/10.1073/pnas.261555198.

O'Halloran, T.L., Law, B.E., Goulden, M.L., Wang, Z., Barr, J.G., Schaaf, C., Brown, M. Fuentes, J.D., Göckede, M., Black, A., Engel, V., 2012. Radiative forcing of natural forest disturbances. Glob. Change Biol. 18 (2), 555-565.

Osawa, A., Zyryanova, O.A., Matsuura, Y., Kajimoto, T., Wein, R.W. (Eds.), 2010. Permafrost Ecosystems. Siberian Larch Forests, vol. 209. Springer Ecological Studies, p. 502.

Ostberg, S., Lucht, W., Schaphoff, S., Gerten, D., 2013. Critical impacts of global warming on land ecosystems. Earth Syst. Dyn. 4 (2), 347-357. http://dx.doi.org/ 10.5194/esd-4-347-2013.

Pan, Y., Birdsey, R.A., Fang, J., Houghton, R., Kauppi, P.E., Kurz, W.A., et al., 2011. A large and persistent carbon sink in the world's forests. Science (New York, N.Y.) 333 (6045), 988-993. http://dx.doi.org/10.1126/science.1201609.

Parmesan, C., Yohe, G., 2003. A globally coherent fingerprint of climate change impacts across natural systems. Nature 421 (6918), 37-42. http://dx.doi.org/ 10.1038/nature01286.

Pavlov, I.N., Zykalov, A.G., 2014. The role of root pathogens in drying coniferous forests of Siberia and Far East. In: Proceedings of All-Russia Sci. Conf., Krasnoyarsk, 16-19 Sept. 2014, pp. 35-38 (in Russian).

Peng, C., Ma, Z., Lei, X., Zhu, O Chen, H., Wang W. Liu, S. Li, W., Fang, X, Zhou, X. 2011. A drought-induced pervasive increase in tree mortality across Canada's boreal forests. Nature Clim. Change 1 (9), 467-471.

Piao, S., Ciais, P., Friedlingstein, P., Peylin, P., Reichstein, M., Luyssaert, S., et al., 2008 Net carbon dioxide losses of northern ecosystems in response to autumn warming. Nature 451 (7174), 49-52. http://dx.doi.org/10.1038/nature06444.

Pleshanov, A.S., 1982. Insects-Defoliators of Larch Forests in East Siberia. Nauka, Novosibirsk, p. 209 (in Russian).

Ponomarev, E.I., Shvetsov, E.G., 2013. Characteristics of vegetation fire categories in Siberia, according to satellite-based and other observations. Invest. Land Space (5), 45-54 (in Russian).

Potapov, P., Hansen, M.C., Stehman, S.V., Loveland, T.R., Pittman, K., 2008 Combining MODIS and Landsat imagery to estimate and map boreal forest cover loss. Rem. Sens. Environ. 112 (9), 3708-3719. http://dx.doi.org/10.1016/j. rse.2008.05.006.

Potapov, P., Turubanova, S., Hansen, M.C., 2011. Regional-scale boreal forest cover and change mapping using Landsat data composites for European Russia. Rem. Sens. Environ. 115 (2), 548-561. http://dx.doi.org/10.1016/j.rse.2010.10.001.

Price, D.T., Alfaro, R.I., Brown, K.J., Flannigan, M.D., Fleming, R.A., Hogg, E.H., Girardin, M.P., Lakusta, T., Johnston, M., McKenney, D.W., Pedlar, J.H., Stratton, T., Sturrock, R.N., Thompson, I.D., Trofymow, J.A., Venier, L.A., 2013. Anticipating the consequences of climate change for Canada's boreal forest ecosystems. Environ. Rev. 21, 322-365. http://dx.doi.org/10.1139/er-2013-0042.

Randerson, J.T., Liu, H., Flanner, M.G., Chambers, S.D., Jin, Y., Hess, P.G., et al., 2006. The impact of boreal forest fire on climate warming. Science (New York, N.Y.) 314 (5802), 1130-1132. http://dx.doi.org/10.1126/science.1132075.

Romanovsky, V.E., Drozdov, D.S., Oberman, N.G., Malkova, G.V., Kholodov, A.L., Marchenko, S.S., et al., 2010. Thermal state of permafrost in Russia. Permafrost Periglac. Process. 21 (2), 136-155. http://dx.doi.org/10.1002/ppp.683.

Schaefer, K., Zhang, T., Bruhwiler, L., Barrett, A.P., 2011. Amount and timing of permafrost carbon release in response to climate warming. Tellus B 63 (2), 165180. http://dx.doi.org/10.1111/j.1600-0889.2011.00527.x.

Schaphoff, S., Lucht, W., Gerten, D., Sitch, S., Cramer, W., Prentice, I.C., 2006. Terrestrial biosphere carbon storage under alternative climate projections. Climatic Change 74 (1-3), 97-122. http://dx.doi.org/10.1007/s10584-005-9002-5. 
Schaphoff, S., Heyder, U., Ostberg, S., Gerten, D., Heinke, J., Lucht, W., 2013. Contribution of permafrost soils to the global carbon budget. Environ. Res. Lett. 8 (1), 014026. http://dx.doi.org/10.1088/1748-9326/8/1/014026.

Scheffer, M., Hirota, M., Holmgren, M., Van Nes, E.H., Chapin, F.S., 2012. Thresholds for boreal biome transitions. Proc. Natl. Acad. Sci. USA 109 (52), 21384-21389. http://dx.doi.org/10.1073/pnas.1219844110.

Schepaschenko, D.G., Mukhortova, L.V., Shvidenko, A.Z., Vedrova, E.F., 2013. The pool of organic carbon in the soil of Russia. Eurasian Soil Sci. 46 (2), 107-116.

Schepaschenko, D.G., Shvidenko, A., Blyshchyk, V., Kraxner, F., 2015a. Reanalysis of live biomass of Russian forests. In: Abstracts of the 17th IBFRA Conference on Towards a New Era of Forest Science in Boreal Region. Rovaniemi, Finland, 2429 May 2015, p. 76.

Schepaschenko, D.G., Shvidenko, A.Z., Lesiv, M.Yu., Kraxner, F., Schepaschenko, M.V. 2015b. Area of Russian forests and its dynamics based on synergy of remote sensing products. For. Sci. (Lesovedenie) 3, 163-171 (in Russian).

Sennov, S.N., 1999. Results of 60-Years Observation of Natural Dynamics of Forests. S.-P. Forestry Research Institute, Saint-Petersburg, p. 93 (in Russian).

Shanin, V.N., Komarov, A.S., Mikhailov, A.V., Bykhovets, S.S., 2011. Modelling carbon and nitrogen dynamics in forest ecosystems of Central Russia under different climate change scenarios and forest management regimes. Ecol. Model. 222 (14), 2262-2275. http://dx.doi.org/10.1016/j.ecolmodel.2010.11.009.

Sharmina, M., Anderson, K., Bows-Larkin, A., 2013. Climate change regional review: Russia. Wiley Interdiscipl. Rev.: Climate Change 4 (5), 373-396.

Shuman, J.K., Shugart, H.H., O'Halloran, T.L., 2011. Sensitivity of Siberian larch forests to climate change. Glob. Change Biol. 17 (7), 2370-2384. http://dx.doi. org/10.1111/j.1365-2486.2011.02417.x

Shvidenko, A., Nilsson, S., 2002. Dynamics of Russian forests and the carbon budget in 1961-1998: an assessment based on long-term forest inventory data. Climatic Change 2, 5-37, <http://link.springer.com/article/10.1023/A: 1020243304744>.

Shvidenko, A., Nilsson, S., 2003. A synthesis of the impact of Russian forests on the global carbon budget for 1961-1998. Tellus 55B, 391-415, <http:/ onlinelibrary.wiley.com/doi/10.1034/j.1600-0889.2003.00046.x/full>

Shvidenko, A.Z., Schepaschenko, D.G., 2013. Climate change and wildfires in Russia. Contemp. Probl. Ecol. 6 (7), 683-692. http://dx.doi.org/10.1134/ S199542551307010X.

Shvidenko, A.Z., Schepaschenko, D.G., 2014. Carbon budget of forests of Russia. Siberian J. For. Sci. 1, 69-92 (in Russian).

Shvidenko, A.Z., Schepaschenko, D.G., Nilsson, S., 2007a. Materials for understanding the present-day productivity of forest ecosystems in Russia. In: Proceeding of the Int. Seminar on Sustainable Forest Management, 6-7 Dec. 2007, Krasnoyarsk, pp. 7-37 (in Russian).

Shvidenko, A., Schepaschenko, D., Nilsson, S., Bouloui, 2007b. Semi-emporica models for assessing biological productivity of Northern Eurasian forests. Ecol. Model. 204, 163-179.

Shvidenko, A., Schepaschenko, D., McCallum, I., Nilsson, S., 2010. Can the uncertainty of full carbon accounting of forest ecosystems be made acceptable to policymakers? Climatic Change 103, 137-157.

Shvidenko, A.Z., Shchepashchenko, D.G., Vaganov, E.A., Sukhinin, A.I., Maksyutov, S S., McCallum, I., Lakyda, I.P., 2011. Impact of wildfire in Russia between 1998 2010 on ecosystems and the global carbon budget. Dokl. Earth Sci. 441 (2) 1678-1682. http://dx.doi.org/10.1134/S1028334X11120075.

Shvidenko, A.Z., Gustafson, E., McGuire, A.D., Kharuk, V.I., Schepaschenko, D.G. Shugart, H.H., et al., 2013. Terrestrial ecosystems and their change. In: Groisman, P.Ya., Gutman, G. (Eds.), Regional Environmental Changes in Siberia and their Global Consequences. Springer, pp. 171-249.

Soja, A.J., Tchebakova, N.M., French, N.H.F., Flannigan, M.D., Shugart, H.H., Stocks, B. J., et al., 2007. Climate-induced boreal forest change: predictions versus current observations. Global Planet. Change 56 (3-4), 274-296. http://dx.doi.org/ 10.1016/j.gloplacha.2006.07.028.

Steinkamp, J., Hickler, T., 2015. Is drought-induced forest dieback globally increasing? J. Ecol. 103, 31-43. http://dx.doi.org/10.1111/1365-2745.12335.

Sukhinin, A.I. (Ed.), 2010. Catastrophic Fires in Siberia. V. Sukachev Institute of Forest SB RAS, Krasnoyarsk, p. 91 (in Russian).

Sukhinin, A.I., 2011. Satellite Data on Wild Fire. <www.iiasa.ac.at/Research? FOR/forest cdrom/index.html> (accessed 5 May 2012).

Tarnocai, C., Canadell, J.G., Schuur, E.A.G., Kuhry, P., Mazhitova, G., Zimov, S., 2009. Soil organic carbon pools in the northern circumpolar permafrost region. Global Biogeochem. Cycles 23, GB202.

Tchebakova, N.M., Parfenova, E.I., 2012. The 21st century climate change effects on the forests and primary conifers in central Siberia. Bosque 33 (3), 253-259.

Tchebakova, N.M., Parfenova, E., Soja, A.J., 2009. The effects of climate, permafrost and fire on vegetation change in Siberia in a changing climate. Environ. Res. Lett. 4 (4), 045013. http://dx.doi.org/10.1088/1748-9326/4/4/045013.

Tchebakova, N.M., Parfenova, E.I., Soja, A.J., 2011. Climate change and climateinduced hot spots in forest shifts in central Siberia from observed data. Reg. Environ. Change 11 (4), 817-827.

Thurner, M., Beer, C., Santoro, M., Carvalhais, N., Wutzler, T., Schepaschenko, D. Shvidenko, A., Kompter, E., Ahrens, B., Levick, S.R., Schmullius, C., 2014. Carbon stock and density of northern boreal and temperate forests. Global Ecol. biogeogr. 23 (3), 297-310.

Udra, I.F., 1988. Setting and Migration of Woody Plants in Temperate Belt of Eurasia. Naukova Dumka, Kiev, p. 200 (in Russian).

Vaganov, E.A., Huges, M.K., Kirdyanov, A.V., Schweingruber, F.H., Silkin, P.P., 1999. Influence of snowmelt and melt timing on tree growth in subarctic Eurasia. Nature 4000, 149-151.

Walker, M.D., Wahren, C.H., Hollister, R.D., Henry, G.H.R., Ahlquist, L.E., Alatalo, J.M., et al., 2006. Plant community responses to experimental warming across the tundra biome. Proc. Natl. Acad. Sci. USA 103 (5), 1342-1346. http://dx.doi.org/ 10.1073/pnas.0503198103.

Warszawski, L., Friend, A., Ostberg, S., Frieler, K., Lucht, W., Schaphoff, S., et al., 2013. A multi-model analysis of risk of ecosystem shifts under climate change. Environ. Res. Lett. 8 (4), 044018. http://dx.doi.org/10.1088/1748-9326/8/4/044018.

Zamolodchikov, D.G., Grabovsky, V.I., Kraev, G.N., 2011. Dynamics of carbon budget of Russia's forests during the last two decades. For. Sci. (Lesovedenie) 6, 16-28 (in Russian)

Zamolodchikov, D.G., Grabovsky, V.I., Shulyak, P.P., Chestnykh, O.V., 2013. The impacts of fires and clear-cuts on the carbon balance of Russian forests. Contemp. Probl. Ecol. 6 (7), 1714-1726. http://dx.doi.org/10.1134/ S1995425513070123.

Zavarzin, G.A. (Ed.), 2007. Carbon Pools and Fluxes in Terrestrial Ecosystems of Russia. Nauka, Moscow, p. 315 (in Russian).

Zhang, K., Kimball, J.S., Hogg, E.H., Zhao, M., Oechel, W.C., Cassano, J.J., Running, S.W., 2008. Satellite-based model detection of recent climate-driven changes in northern high-latitude vegetation productivity. J. Geophys. Res.: Biogeosci. (2005-2012) 113 (G3)

Zhang, N., Shugart, H.H., Yan, X., 2009. Simulating the effects of climate changes on Eastern Eurasia forests. Climatic Change 95 (3-4), 341-361. http://dx.doi.org/ 10.1007/s10584-009-9568-4.

Zhang, N., Yasunari, T., Ohta, T., 2011. Dynamics of the larch taiga-permafrost coupled system in Siberia under climate change. Environ. Res. Lett. 6 (2), 024003. http://dx.doi.org/10.1088/1748-9326/6/2/024003.

Zhao, M., Running S.W., 2010. Drought-induced reduction in global terrestrial net primary production from 2000 through 2009. Science 329 (5994), 940-943.

Zimov, S.A., Schuur, E.A.G., Chapin, F.S., 2006. Permafrost and the global carbon budget. Science 312, 1612-1613. 